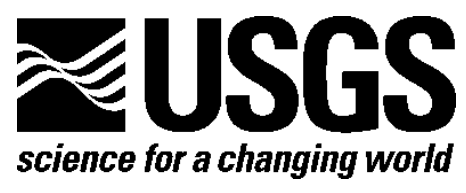

Prepared in cooperation with the

DuPage County Stormwater Management Department

\title{
Comparison of NEXRAD Multisensor Precipitation Estimates to Rain Gage Observations in and near DuPage County, Illinois, 2002-12
}

By Ryan R. Spies, Thomas M. Over, and Terry W. Ortel

Open-File Report 2018-1061

U.S. Department of the Interior U.S. Geological Survey 


\section{U.S. Department of the Interior \\ RYAN K. ZINKE, Secretary}

\section{U.S. Geological Survey James F. Reilly II, Director}

U.S. Geological Survey, Reston, Virginia: 2018

For more information on the USGS - the Federal source for science about the Earth, its natural and living resources, natural hazards, and the environment-visit https://www.usgs.gov/ or call 1-888-ASK-USGS (1-888-275-8747).

For an overview of USGS information products, including maps, imagery, and publications, visit https://store.usgs.gov/.

Any use of trade, firm, or product names is for descriptive purposes only and does not imply endorsement by the U.S. Government.

Although this information product, for the most part, is in the public domain, it also may contain copyrighted materials as noted in the text. Permission to reproduce copyrighted items must be secured from the copyright owner.

Suggested citation:

Spies, R.R., Over, T.M., and Ortel, T.W., 2018, Comparison of NEXRAD multisensor precipitation estimates to rain gage observations in and near DuPage County, Illinois, 2002-12: U.S. Geological Survey Open-File Report 2018-1061, 30 p., https://doi.org/10.3133/ofr20181061.

ISSN 2331-1258 (online) 


\section{Contents}

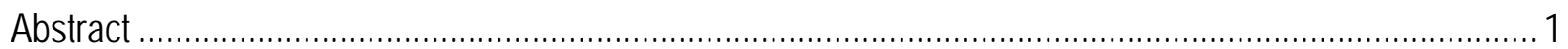

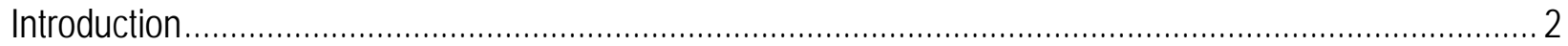

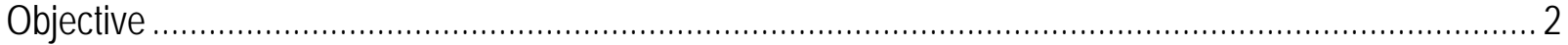

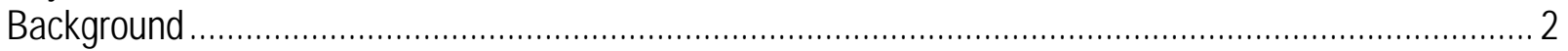

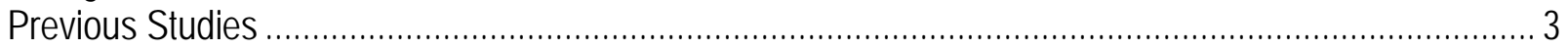

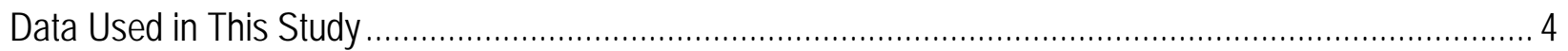

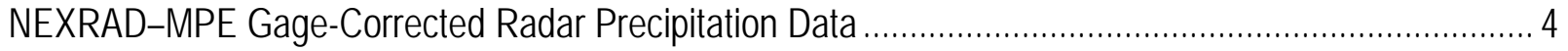

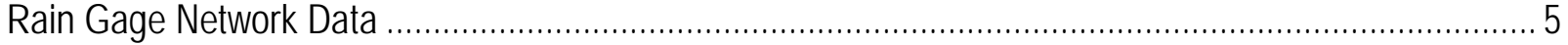

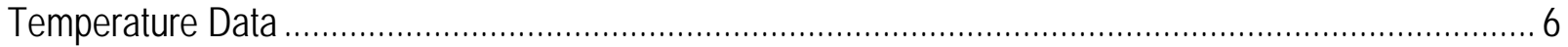

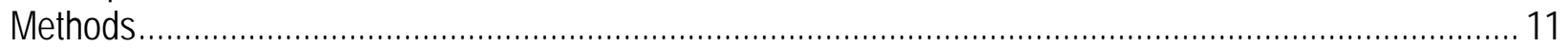

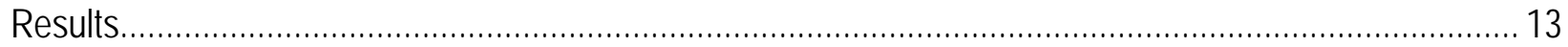

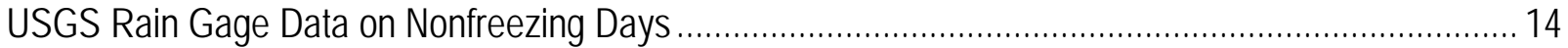

NEXRAD-MPE Precipitation Data on Nonfreezing Days ……….................................................... 15

USGS Rain Gage Data on Freezing Days ……………............................................................ 16

NEXRAD-MPE Precipitation Data on Freezing Days ................................................................. 17

Summary of Cumulative Spatial and Total By-Gage Comparisons ....................................................... 18

NEXRAD-MPE-Gage Differences and Gage-to-Radar Distance ................................................... 19

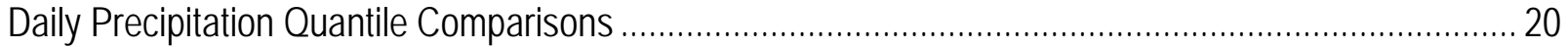

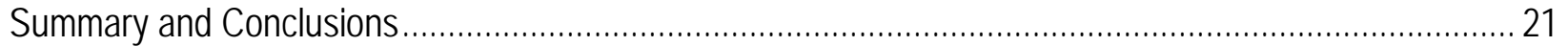

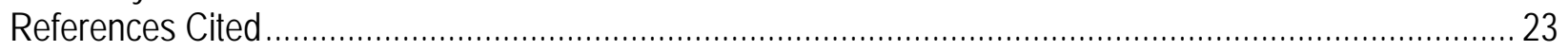

Appendix 1. Daily Precipitation Quantile Comparisons by Year............................................................... 25

Appendix 2. Dependence of NEXRAD-MPE Precipitation on Temperature .......................................... 27

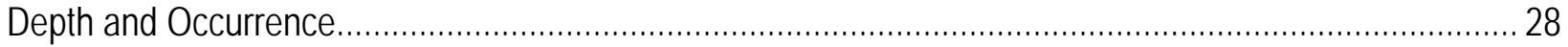

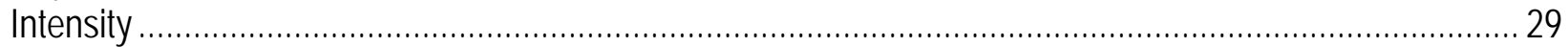

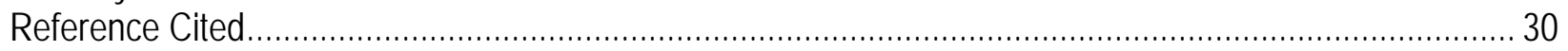

\section{Figures}

1. Graph showing comparison of cumulative average Next-Generation Radar (NEXRAD) precipitation estimates and cumulative avearage gage precipitation from July 1997 through September 2005 for all nonremoved days ................................................................................................... 3

2. $\quad$ Map showing U.S. Geological Survey (USGS) rain gages used in this study ............................... 8

3. Map showing Community Cooperative Rain, Hail, and Snow (CoCoRaHS) network rain gages used

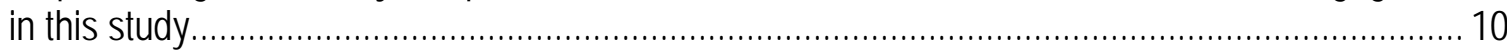

4. Graphs showing relation of USGS rain gage precipitation to precipitation from CoCoRaHS network rain gages and NEXRAD-MPE gage-corrected radar on nonfreezing days................................ 14

5. Graphs showing relation of NEXRAD-MPE gage-corrected radar precipitation to precipitation from CoCoRaHS network rain gages on nonfreezing days.......................................................... 15

6. Graphs showing relation of USGS rain gage precipitation to precipitation from CoCoRaHS network rain gages and NEXRAD-MPE gage-corrected radar on freezing days..................................... 16

7. Graphs showing relation of NEXRAD-MPE gage-corrected radar precipitation to precipitation from CoCoRaHS network rain gages on freezing days. 
8. Graphs showing relations between NEXRAD-MPE-gage differences and gage-to-radar distance.

9. Graphs showing relations between daily precipitation quantiles and exceedance probability ........20 20

1-1. Graphs showing comparison of daily precipitation quantiles by year during nonfreezing days....... 26

1-2. Graphs showing comparison of daily precipitation quantiles by year during freezing days............. 26

2-1. Graph showing spatial mean total NEXRAD-MPE precipitation depth and temperature frequency by temperature using data from Feb.1, 2002, through Sept. 30, 2012

2-2. Graph showing fraction of hours with NEXRAD-MPE precipitation by temperature using data from Feb.1, 2002, through Sept. 30, 2012 28

2-3. Graph showing spatial mean NEXRAD-MPE hourly average precipitation intensity by temperature during all hours from Feb.1, 2002, through Sept. 30, 2012.

2-4. Graph showing spatial mean NEXRAD-MPE hourly average precipitation intensity by termperature during hours with reported precipitation from Feb.1, 2002, through Sept. 30, 2012 29

\section{Tables}

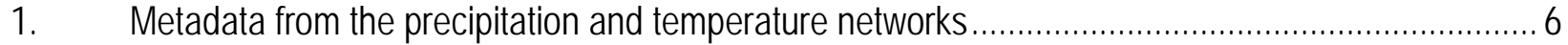

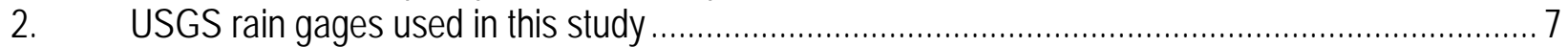

3. CoCoRaHS network rain gages used in this study ............................................................. 9

4. Summary of cumulative spatial average and total by-gage comparison results............................. 18 


\section{Conversion Factors}

U.S. customary units to International System of Units

\begin{tabular}{|c|c|c|}
\hline Multiply & By & To obtain \\
\hline \multicolumn{3}{|c|}{ Length } \\
\hline inch (in.) & 2.54 & centimeter $(\mathrm{cm})$ \\
\hline inch (in.) & 25.4 & millimeter (mm) \\
\hline mile (mi) & 1.609 & kilometer (km) \\
\hline \multicolumn{3}{|c|}{ Flow rate } \\
\hline inch per hour (in/h) & 25.4 & millimeter per hour (mm/h) \\
\hline
\end{tabular}

Temperature in degrees Fahrenheit $\left({ }^{\circ} \mathrm{F}\right)$ may be converted to degrees Celsius $\left({ }^{\circ} \mathrm{C}\right)$ as follows:

$$
{ }^{\circ} \mathrm{C}=\left({ }^{\circ} \mathrm{F}-32\right) / 1.8 \text {. }
$$

\section{Datum}

Horizontal coordinate information is referenced to the North American Datum of 1927 (NAD 27).

\section{Abbreviations}

$\begin{array}{ll}\text { ANL } & \text { Argonne National Laboratory } \\ \text { CoCoRaHS } & \text { Community Collaborative Rain, Hail and Snow } \\ \text { CSA } & \text { cumulative spatial average } \\ \text { DPC-FFSS } & \text { DuPage County flood forecast simulation system } \\ \text { HRAP } & \text { Hydrologic Research Analysis Project } \\ \text { LDM } & \text { Local Data Manager } \\ \text { MPE } & \text { Multisensor Precipitation Estimate } \\ \text { NCRFC } & \text { North Central River Forecast Center } \\ \text { NEXRAD } & \text { Next-Generation Radar } \\ \text { NOAA } & \text { National Oceanic and Atmospheric Administration } \\ \text { NWS } & \text { National Weather Service } \\ \text { PADJ } & \text { precipitation adjustment factor } \\ \text { USGS } & \text { U.S. Geological Survey }\end{array}$





\title{
Comparison of NEXRAD Multisensor Precipitation Estimates to Rain Gage Observations in and near DuPage County, Illinois, 2002-12
}

\author{
By Ryan R. Spies, Thomas M. Over, and Terry W. Ortel
}

\begin{abstract}
In this report, precipitation data from 2002 to 2012 from the hourly gridded NextGeneration Radar (NEXRAD)-based Multisensor Precipitation Estimate (MPE) precipitation product are compared to precipitation data from two rain gage networks - an automated tipping bucket network of 25 rain gages operated by the U.S. Geological Survey (USGS) and 51 rain gages from the volunteer-operated Community Collaborative Rain, Hail, and Snow (CoCoRaHS) network - in and near DuPage County, Illinois, at a daily time step to test for long-term differences in space, time, and distribution. The NEXRAD-MPE data that are used are from the fifty 2.5-mile grid cells overlying the rain gages from the other networks. Because of the challenges of measuring of frozen precipitation, the analysis period is separated between days with or without the chance of freezing conditions. The NEXRAD-MPE and tipping-bucket rain gage precipitation data are adjusted to account for undercatch by multiplying by a previously determined factor of 1.14. Under nonfreezing conditions, the three precipitation datasets are broadly similar in cumulative depth and distribution of daily values when the data are combined spatially across the networks. However, the NEXRAD-MPE data indicate a significant trend relative to both rain gage networks as a function of distance from the NEXRAD radar just south of the study area. During freezing conditions, of the USGS network rain gages only the heated gages were considered, and these gages indicate substantial mean undercatch of 50 and 61 percent compared to the NEXRAD-MPE and the CoCoRaHS gages, respectively. The heated USGS rain gages also indicate substantially lower quantile values during freezing conditions, except during the most extreme (highest) events. Because NEXRAD precipitation products are continually evolving, the report concludes with a discussion of recent changes in those products and their potential for improved precipitation estimation. An appendix provides an analysis of spatially combined NEXRAD-MPE precipitation data as a function of temperature at an hourly time scale and indicates, among other results, that most precipitation in the study area occurs at moderate temperatures of 30 to 74 degrees Fahrenheit. However, when precipitation does occur, its intensity increases with temperature to about 86 degrees Fahrenheit.
\end{abstract}




\section{Introduction}

\section{Objective}

Evaluate the differences between the Next-Generation Radar (NEXRAD)-Multisensor Precipitation Estimates (MPE) and U.S. Geological Survey (USGS) rain gage data in and near DuPage County, Illinois, by comparing both data sources to daily precipitation observations from the Community Collaborative Rain, Hail, and Snow (CoCoRaHS) network.

\section{Background}

- The USGS assists DuPage County Stormwater Management Department with simulations of flood forecasts using the DuPage County flood forecast simulation system (DPC-FFSS) (Ishii and others, 1998).

- NEXRAD-MPE and USGS tipping-bucket rain gage precipitation data are currently (2018) used as alternate precipitation inputs to the system (Ishii and others, 2003; Ortel and Spies, 2015).

- Determining the accuracy of these precipitation data is critical for selecting the precipitation data source for flood forecast simulation and predicting the simulation accuracy.

- The analysis distinguishes between liquid and frozen precipitation events based on an hourly temperature record and temperature threshold criterion from Over and others (2007).

- This report is, in part, a continuation of the analysis by Over and others (2007) and covers the period from Feb. 1, 2002, through Sept. 30, 2012, including freezing days, which Over and others (2007) excluded. The results of Over and others (2007) and other published studies comparing precipitation estimates based on data from NEXRAD and rain gages are summarized in the "Previous Studies" section. 


\section{Previous Studies}

- Over and others (2007) compared NEXRAD data to the DuPage County gage network for the years 1997-2005 excluding freezing days. Significant findings included:

o After discrepancies during 1997-2001, the long-term spatial averages of NEXRAD-MPE and the DuPage County gage network data were similar for the 2002-5 period that overlaps with the period of this study (fig. 1).

0 The probability distribution of daily rainfall values indicated that the radar data exhibit more small values and fewer large values than the gage data.

o Differences between gage and NEXRAD total precipitation decreased with distance from the nearby KLOT radar site in Romeoville, Illinois (figs. 2, 3).

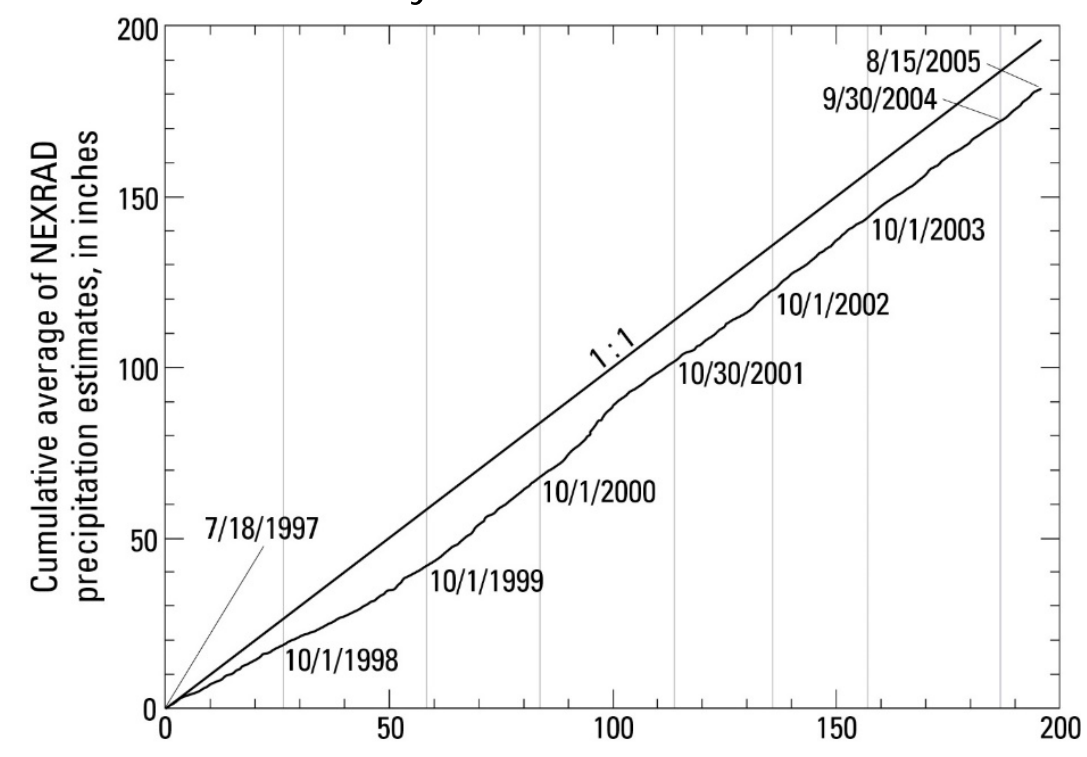

Cumulative average of gage precipitation, in inches

Figure 1. Comparison of cumulative average Next-Generation Radar (NEXRAD) precipitation estimates and cumulative average gage precipitation from July 1997 though September 2005 for all nonremoved days (from Over and others, 2007).

- Westcott and Knapp (2006) also compared NEXRAD-MPE data to radar-only and rain gage-only observations. Westcott and Knapp (2006) selected the Fox River Basin in northeastern Illinois and southeastern Wisconsin as their study domain and used data from February 2002 through September 2004. Significant findings include:

o The MPE product showed considerable improvement compared to the radar-only product for all four seasons.

- The MPE data were 25 percent lower than the daily rain gage records when averaged for the year.

- Additional NEXRAD and rain gage comparison studies include Young and others (2000), Jayakrishnan and others (2004), Westcott and others (2008), Kim and Brubaker (2014), and Price and others (2014). 


\section{Data Used in this Study}

\section{NEXRAD-MPE Gage-Corrected Radar Precipitation Data}

- Data Production by the National Weather Service:

o NEXRAD-MPE data combine hourly precipitation estimates from Weather Surveillance Radar 1988 Doppler radars on the 2.5-mile Hydrologic Research Analysis Project (HRAP) grid (Fulton, 1998) with quality-controlled rain gage data to create a "multisensor" product.

o Rain gage data retrieved from the National Weather Service (NWS) and the regional observing networks through local government and utility agencies are used to bias-correct the radar-only NEXRAD data.

- NEXRAD-MPE data for DuPage County and the surrounding area are produced by the NWS North Central River Forecast Center (NCRFC). NEXRAD-MPE data are obtained hourly by the USGS from the NCRFC through a Local Data Manager (LDM) feed. Updated hourly datasets are sometimes provided and replace the original dataset.

- NEXRAD-MPE data, as obtained from a river forecast center with updates, are similar to the mosaic of real-time NEXRAD-MPE data known as "Stage IV," but there are important differences between them because of the updates, which include additional quality control (Eldardiry and others, 2017).

o See Kitzmiller and others (2013) for additional NEXRAD-MPE production details.

- Data Processing for this Study:

o NEXRAD-MPE data from the 50 different HRAP cells overlying the rain gages considered in this study (figs. 2, 3) were used.

o See Ortel and Spies (2015) for more information on NEXRAD-MPE data retrieval and processing by the USGS for the DPC-FFSS. 


\section{Rain Gage Network Data}

- NEXRAD-MPE data are compared to data from two rain gage networks in this study:

1. USGS DuPage County rain gage network (tables 1, 2; fig. 2)-25 gages (11 heated), daily data (midnight-to-midnight). These data were obtained from the USGS National Water Information System (U.S. Geological Survey, 2014).

2. CoCoRaHS network (tables 1, 3; fig. 3)-51 gages in and near DuPage County with daily observations at about 7 a.m. local time. Data were obtained from the Global Historical Climatology Network (National Oceanic and Atmospheric Administration, 2014).

- Gage specifications:

1. USGS gages: Automated 6-, 8-, or 12-inch (in.) tipping-bucket rain gages with realtime transmission of tip data and, for most gages, dataloggers, were used. When available, the logged data were used as the primary data to avoid errors resulting from transmission problems. Gages were maintained and calibrated according to USGS standards. Data were checked by comparison with values at neighboring stations, and, during some years, missing and freezing-affected data were estimated by comparison with values at neighboring stations. See Murphy and Ishii (2006), Bera (2014), and Bera (2017) for more information.

Some missing data were estimated from nearby gages (Murphy and Ishii, 2006; Bera, 2014). These estimated data were included in the analysis. During potentially freezing conditions as defined in this study, only data from heated gages were used.

2. CoCoRaHS network gages (https://cocorahs.org): Daily measurements were made by trained volunteer observers using an unshielded, 4-in. diameter, 11.3-in. capacity gage that provides measurements of rain and liquid-water equivalent of frozen precipitation.

CoCoRaHS network equipment and measurement procedures are similar to NWS cooperative observer network gages and are present at a higher density in populated areas (Reges and others, 2016). Multiple local operational flood-control agencies and peer-reviewed scientific studies have used CoCoRaHS data as the basis for adjusting automated tipping-bucket or radar-based precipitation data (Reges and others, 2016; Simpson and others, 2017)

Because of the high density of CoCoRaHS gages in the study area and their relative accuracy for both liquid and frozen precipitation, CoCoRaHS data are taken as the basis for evaluation of precipitation estimates from both the NEXRAD-MPE and the USGS rain gages in this study. 


\section{Temperature Data}

- $\quad$ Hourly temperature data from the Argonne National Laboratory (ANL, figs. 2, 3) temperature record processed by the USGS (Murphy and Ishii, 2006; Over and others, 2010) were used (table 1).

- $\quad$ ANL-USGS temperature data are available in Bera and Over (2016).

$\underline{\text { Table 1. Metadata from the precipitation and temperature networks. }}$

[USGS, U.S. Geological Survey; CoCoRaHS, Community Collaborative Rain, Hail and Snow; NOAA, National Oceanic and Atmospheric Administration; NCEI, National Centers for Environmental Information; NEXRAD-MPE, Next-Generation Radar-Multisensor Precipitation Estimate; NWS, National Weather Service; NCRFC, North Central River Forecast Center ; --, no data; dates are expressed as month/day/year]

\begin{tabular}{lllccc}
\hline \multicolumn{1}{c}{ Precipitation network- } & Data provider & $\begin{array}{c}\text { Time period of } \\
\text { available data }\end{array}$ & $\begin{array}{c}\text { Days in study } \\
\text { period }\end{array}$ & $\begin{array}{c}\text { Missing } \\
\text { days }^{1}\end{array}$ & $\begin{array}{c}\text { Daily data } \\
\text { definition }\end{array}$ \\
\hline USGS tipping-bucket gages & USGS & $2 / 1 / 2002-9 / 30 / 2012$ & 3,895 & 34 & 12 a.m. -12 a.m. \\
CoCoRaHS standard gages & NOAA-NCEI & $2 / 1 / 2007-9 / 30 / 2012$ & 2,069 & 48 & 7 a.m. -7 a.m. \\
NEXRAD-MPE & NWS, NCRFC & $2 / 1 / 2002-9 / 30 / 2012$ & -- & -- & Match gage $^{2}$ \\
\hline
\end{tabular}

${ }^{1}$ Missing days are defined using a criterion given in the "Methods" section.

${ }^{2}$ The 24-hour period is selected to match the rain gage network daily data definition.

[ANL, Argonne National Laboratory; USGS, U.S. Geological Survey; dates are expressed as month/day/year]

\begin{tabular}{llccc}
\hline \multicolumn{1}{c}{ Temperature network } & Data provider & Time period & Freezing days & Nonfreezing days \\
\hline ANL & ANL-USGS & $32 / 1 / 2002-9 / 30 / 2012$ & 1,153 & 2,742 \\
ANL & ANL-USGS & $32 / 1 / 2007-9 / 30 / 2012$ & 604 & 1,465 \\
\hline
\end{tabular}

${ }^{3}$ Data are separated into two periods to match the record of available data for the precipitation networks. 
Table 2. USGS rain gages used in this study.

[USGS, U.S. Geological Survey; ID, identification number; NEXRAD, Next-Generation Radar; IL, Illinois; WWTF, wastewater treatment facility; --. Not known to have been heated during study period]

\begin{tabular}{|c|c|c|c|c|c|c|c|}
\hline $\begin{array}{c}\text { Map site } \\
\text { number } \\
\text { (fig. 2) }\end{array}$ & USGS station name & Latitude & Longitude & $\begin{array}{l}\text { USGS station } \\
\text { ID }\end{array}$ & Heated $^{1}$ & $\begin{array}{c}\text { Days of } \\
\text { data }\end{array}$ & $\begin{array}{c}\text { NEXRAD } \\
\text { cell ID }\end{array}$ \\
\hline 1 & SALT CREEK AT ELMHURST, IL & 41.89 & -87.96 & 05531300 & Yes & 3,881 & 70088 \\
\hline 2 & SALT CREEK AT 22ND STREET AT OAK BROOK, IL & 41.85 & -87.94 & 05531410 & -- & 3,703 & 69639 \\
\hline 3 & WEST BRANCH DU PAGE RIVER NEAR NAPERVILLE, IL & 41.72 & -88.13 & 05540130 & -- & 2,739 & 67836 \\
\hline 4 & BOLINGBROOK WWTF AT BOLINGBROOK, IL & 41.72 & -88.07 & 414306088042100 & -- & 3,822 & 67837 \\
\hline 5 & NAPERVILLE N OPERATIONS CENTER AT NAPERVILLE, IL & 41.73 & -88.17 & 414655088102300 & -- & 3,687 & 68285 \\
\hline 6 & WESTMONT WATER DEPARTMENT AT WESTMONT, IL & 41.80 & -87.97 & 414747087582700 & -- & 2,757 & 69188 \\
\hline 7 & MORTON ARBORETUM NEAR LISLE, IL & 41.81 & -88.07 & 414843088042500 & -- & 3,368 & 69187 \\
\hline 8 & BLACKWELL FOREST PRESERVE NEAR WARRENVILLE, IL & 41.84 & -88.19 & 415037088110600 & -- & 3,337 & 69184 \\
\hline 9 & ADDISON WWTF AT ADDISON, IL & 41.92 & -87.98 & 415518087583000 & -- & 3,717 & 70538 \\
\hline 10 & BARTLETT WWTF NEAR BARTLETT, IL & 41.97 & -88.17 & 415801088095700 & -- & 3,644 & 70534 \\
\hline 11 & SPRING BROOK WWTF NR NAPERVILE, IL & 41.70 & -88.17 & 414158088095600 & Yes & 2,214 & 67386 \\
\hline 12 & WOODRIDGE WWTF AT WOODRIDGE, IL & 41.74 & -88.07 & 414430088035600 & Yes & 3,740 & 68287 \\
\hline 13 & NAPERVILLE MUNICIPAL BUILDING AT NAPERVILLE, IL & 41.77 & -88.15 & 414613088091000 & Yes & 3,853 & 68285 \\
\hline 14 & OAK BROOK LIFT STATION AT OAK BROOK, IL & 41.84 & -87.97 & 415037087581700 & Yes & 3,710 & 69638 \\
\hline 15 & WHEATON SEWER DEPARTMENT AT WHEATON, IL & 41.86 & -88.08 & 415125088045700 & Yes & 3,404 & 69636 \\
\hline 16 & WHEATON WATER DEPARTMENT AT WHEATON, IL & 41.88 & -88.10 & 415300088054600 & Yes & 3,706 & 69636 \\
\hline 17 & ELMHURST QUARRY AT ELMHURST, IL & 41.90 & -87.96 & 415356087575000 & Yes & 3,760 & 70088 \\
\hline 18 & BLOOMINGDALE LIFT STATION AT BLOOMINGDALE, IL & 41.95 & -88.09 & 415651088051900 & Yes & 3,172 & 70535 \\
\hline 19 & WOOD DALE WWTF AT WOOD DALE, IL & 41.96 & -87.99 & 415751087591000 & Yes & 3,591 & 70987 \\
\hline 20 & OHARE AIRPORT AT CHICAGO, IL & 41.97 & -87.88 & 415755087525300 & -- & 2,932 & 70989 \\
\hline 21 & SCHAUMBURG PUBLIC WORKS AT SCHAUMBURG, IL & 42.01 & -88.06 & 420052088034200 & Yes & 3,271 & 71435 \\
\hline 22 & MARIENBROOK WWTF AT DARIEN, IL & 41.74 & -87.96 & 414411087575000 & -- & 3,521 & 68289 \\
\hline 23 & SAWMILL CREEK NEAR LEMONT, IL & 41.71 & -87.96 & 05533400 & -- & 3,423 & 68289 \\
\hline 24 & RAIN GAGE AT HARPER COLLEGE AT PALATINE, IL & 42.08 & -88.08 & 420453088043200 & -- & 1,294 & 71884 \\
\hline 25 & RAIN GAGE AT SUNDLING JR HS AT PALATINE, IL & 42.13 & -88.05 & 420745088025901 & -- & 934 & 72785 \\
\hline
\end{tabular}

${ }^{1}$ Records of the heating of gages are not complete for all gages throughout the study period; gages indicated in this table as heated were assumed to be so throughout the study period. 


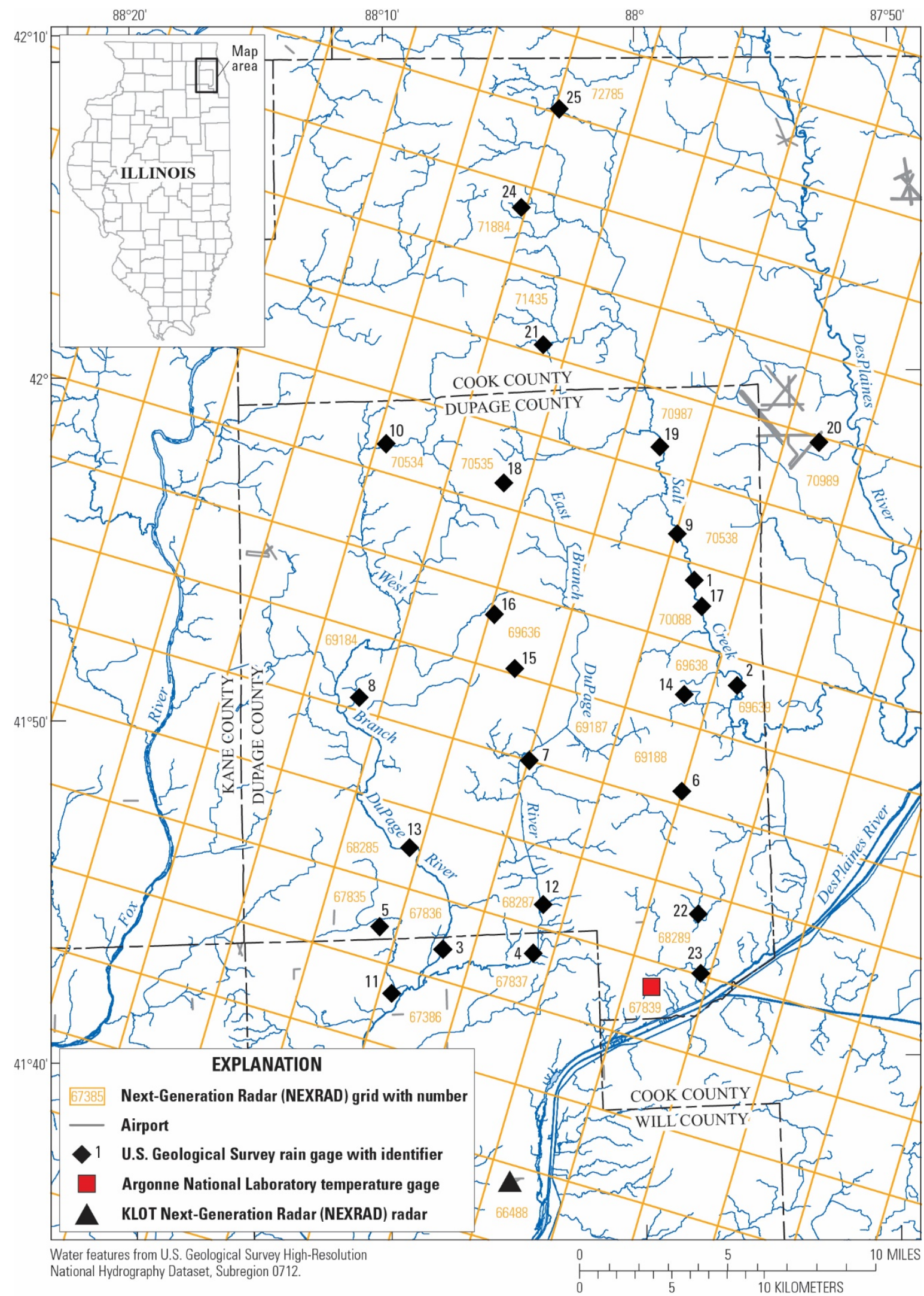

Figure 2. U.S. Geological Survey (USGS) rain gages used in this study.

Note: The USGS rain gage identifiers in this map match map site numbers in table 2 . 
Table 3. CoCoRAHS network rain gages used in this study.

[CoCoRaHS, Community Cooperative Rain, Hail, and Snow; ID, identification number; NEXRAD, Next-Generation Radar; IL, Illinois; US, United States; N, north; NNE, north northeast; NE; northeast; ENE, east northeast; E, east; ESE, east southeast; SE, southeast; SSE, south southwest; S, south; SSW, south southwest; SW, southwest; WSW, west southwest; W, west; WNW, west northwest; NW, northwest; NNW, north northwest.]

\begin{tabular}{|c|c|c|c|c|c|c|}
\hline $\begin{array}{l}\text { Map site } \\
\text { number } \\
\text { (fig. 3) }\end{array}$ & Site ID & Station name & Latitude & Longitude & $\begin{array}{c}\text { Days of } \\
\text { data }\end{array}$ & $\begin{array}{c}\text { NEXRAD } \\
\text { cell ID }\end{array}$ \\
\hline 1 & US1ILDP0074 & NAPERVILLE 1.9 ENE IL US & 41.7682 & -88.1174 & 1,487 & 68286 \\
\hline 2 & US1ILDP0075 & NAPERVILLE 1.1 NW IL US & 41.7729 & -88.1713 & 933 & 68285 \\
\hline 3 & US1ILDP0077 & ROSELLE 1.1 W IL US & 41.9778 & -88.1036 & 1,714 & 70535 \\
\hline 4 & US1ILDP0079 & BURR RIDGE 1.9 SW IL US & 41.7319 & -87.9486 & 1,655 & 68289 \\
\hline 5 & US1ILCK0081 & ARLINGTON HEIGHTS 1.8 NNW IL US & 42.1192 & -87.9951 & 1,703 & 72786 \\
\hline 6 & US1ILCK0087 & ARLINGTON HEIGHTS 1.3 SW IL US & 42.0822 & -88.0019 & 1,031 & 72336 \\
\hline 7 & US1ILDP0047 & GLEN ELLYN 1.4 SE IL US & 41.8515 & -88.0453 & 1,817 & 69637 \\
\hline 8 & US1ILDP0040 & LOMBARD 1.0 NNW IL US & 41.8884 & -88.0229 & 2,254 & 70087 \\
\hline 9 & US1ILDP0042 & CAROL STREAM 0.3 SSE IL US & 41.9130 & -88.1294 & 2,265 & 70085 \\
\hline 10 & US1ILDP0101 & AURORA 3.8 SE IL US & 41.7304 & -88.2376 & 1,061 & 67834 \\
\hline 11 & US1ILDP0102 & BOLINGBROOK 2.7 NE IL US & 41.7302 & -88.0448 & 961 & 68288 \\
\hline 12 & US1ILCK0143 & INVERNESS 1.7 S IL US & 42.0904 & -88.0949 & 1,602 & 71884 \\
\hline 13 & US1ILWL0044 & NAPERVILLE 3.6 SSW IL US & 41.7146 & -88.1807 & 1,192 & 67385 \\
\hline 14 & US1ILDP0030 & LISLE 0.5 WSW IL US & 41.7900 & -88.0979 & 1,338 & 68736 \\
\hline 15 & US1ILDP0058 & WHEATON 0.5 W IL US & 41.8548 & -88.1174 & 1,991 & 69185 \\
\hline 16 & US1ILDP0052 & DARIEN 2.4 SSW IL US & 41.7185 & -87.9996 & 1,128 & 68289 \\
\hline 17 & US1ILCK0131 & SCHAUMBURG 2.0 E IL US & 42.0303 & -88.0440 & 1,028 & 71435 \\
\hline 18 & US1ILCK0137 & MELROSE PARK 2.0 NW IL US & 41.9200 & -87.8855 & 1,003 & 70539 \\
\hline 19 & US1ILDP0057 & AURORA 3.5 NE IL US & 41.8089 & -88.2528 & 1,409 & 68283 \\
\hline 20 & US1ILCK0129 & SCHAUMBURG 2.7 WSW IL US & 42.0135 & -88.1289 & 1,550 & 70984 \\
\hline 21 & US1ILCK0046 & DES PLAINES 0.5 NW IL US & 42.0398 & -87.9083 & 1,333 & 71888 \\
\hline 22 & US1ILDP0028 & WEST CHICAGO 1.0 SE IL US & 41.8791 & -88.2099 & 1,986 & 69183 \\
\hline 23 & US1ILDP0027 & NAPERVILLE 2.1 ESE IL US & 41.7564 & -88.1135 & 2,381 & 68286 \\
\hline 24 & US1ILCK0121 & PALATINE 1.3 E IL US & 42.1139 & -88.0178 & 2,123 & 72335 \\
\hline 25 & US1ILDP0024 & LISLE 0.6 W IL US & 41.7918 & -88.0994 & 1,023 & 68736 \\
\hline 26 & US1ILDP0020 & NAPERVILLE 3.2 ESE IL US & 41.7423 & -88.0982 & 2,091 & 68287 \\
\hline 27 & US1ILDP0029 & GLEN ELLYN 1.6 SSE IL US & 41.8441 & -88.0554 & 1,823 & 69187 \\
\hline 28 & US1ILDP0083 & LOMBARD 1.2 NNW IL US & 41.8912 & -88.0223 & 1,549 & 70087 \\
\hline 29 & US1ILDP0085 & VILLA PARK 1.0 NW IL US & 41.8969 & -87.9903 & 1,568 & 70087 \\
\hline 30 & US1ILDP0087 & ROSELLE 1.2 ESE IL US & 41.9766 & -88.0598 & 1,087 & 70986 \\
\hline 31 & US1ILDP0086 & LISLE 0.5 W IL US & 41.7920 & -88.0967 & 1,095 & 68736 \\
\hline 32 & US1ILKN0001 & GENEVA 1.6 ENE IL US & 41.8941 & -88.2884 & 2,299 & 69182 \\
\hline 33 & US1ILKN0009 & ELGIN 1.0 S IL US & 42.0256 & -88.2885 & 2,365 & 70981 \\
\hline 34 & US1ILDP0038 & ELMHURST 0.4 SW IL US & 41.8935 & -87.9485 & 927 & 70088 \\
\hline 35 & US1ILDP0034 & WEST CHICAGO 2.7 N IL US & 41.9288 & -88.2175 & 2,334 & 70083 \\
\hline 36 & US1ILCK0058 & STREAMWOOD 1.1 SW IL US & 42.01 & -88.19 & 1,432 & 70983 \\
\hline 37 & US1ILDP0032 & LISLE 1.3 SE IL US & 41.7814 & -88.0674 & 2,402 & 68737 \\
\hline 38 & US1ILWL0031 & BOLINGBROOK 3.5 W IL US & 41.6935 & -88.1444 & 1,083 & 67386 \\
\hline 39 & US1ILDP0098 & DOWNERS GROVE 0.9 S IL US & 41.7840 & -88.0168 & 741 & 68738 \\
\hline 40 & US1ILDP0090 & HANOVER PARK 2.2 SSW IL US & 41.9551 & -88.1588 & 1,056 & 70534 \\
\hline 41 & US1ILDP0016 & AURORA 3.6 SE IL US & 41.7346 & -88.2391 & 2,543 & 67834 \\
\hline 42 & US1ILCK0063 & ELK GROVE VILLAGE 0.6 ESE IL US & 42.0039 & -87.9813 & 2,426 & 71437 \\
\hline 43 & US1ILCK0106 & HOFFMAN ESTATES 4.6 W IL US & 42.0597 & -88.2334 & 2,047 & 71432 \\
\hline 44 & US1ILDP0063 & BARTLETT 1.0 SSE IL US & 41.9641 & -88.2014 & 1,906 & 70533 \\
\hline 45 & US1ILDP0060 & GLEN ELLYN 0.8 NW IL US & 41.8739 & -88.0744 & 1,281 & 69636 \\
\hline 46 & US1ILDP0069 & GLEN ELLYN 1.0 NE IL US & 41.8786 & -88.0505 & 1,921 & 69636 \\
\hline 47 & US1ILCK0075 & ELK GROVE VILLAGE 2.2 WSW IL US & 41.9953 & -88.0527 & 2,484 & 70986 \\
\hline 48 & US1ILCK0177 & STREAMWOOD 0.6 W IL US & 42.0217 & -88.1846 & 772 & 70983 \\
\hline 49 & US1ILDP0014 & WESTMONT 1.2 SSE IL US & 41.7811 & -87.9641 & 2,253 & 68739 \\
\hline 50 & US1ILDP0011 & CAROL STREAM 0.7 WNW IL US & 41.9217 & -88.1434 & 1,404 & 70084 \\
\hline 51 & US1ILDP0018 & DOWNERS GROVE 2.1 SE IL US & 41.7716 & -87.9940 & 2,358 & 68738 \\
\hline
\end{tabular}




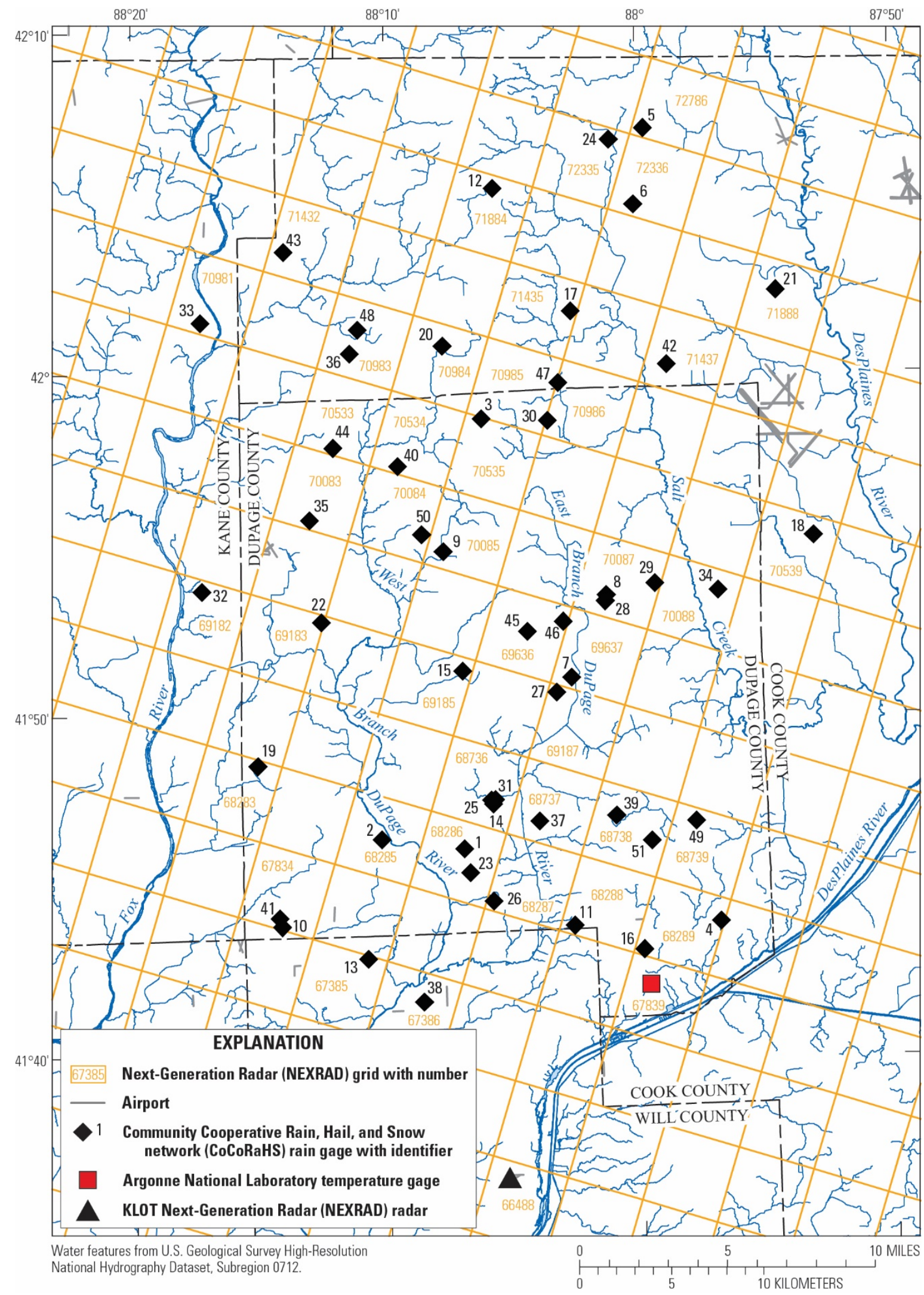

Figure 3. Community Cooperative Rain, Hail, and Snow (CoCoRaHS) rain gages used in this study.

Note: The CoCoRaHS rain gage identifiers match map site numbers in table 3. 


\section{Methods}

- Ground truth: Because of the advantages of CoCoRaHS data compared to automated tipping-bucket rain gages discussed in the section "Data Used in this Study," the CoCoRaHS data are treated as the ground-truth data set to which the NEXRAD-MPE and USGS rain gage data are compared.

- Time step: The rain gage data used in this study were archived at a daily time step and are analyzed as such. To compare the rain gage data, the NEXRAD-MPE were aggregated to daily according to the definitions of days used by the rain gage networks-USGS gages at midnight local standard time and CoCoRaHS gages at approximately 7 a.m. local time.

- NEXRAD-gage matching: Rain gages are matched to their overlying NEXRAD HRAP cells for comparison.

- Freezing/nonfreezing days: Data were sorted into two temperature-indexed categories based on the hourly temperature data from the ANL temperature record (Murphy and Ishii, 2006; Over and others, 2010) using the criteria from Over and others (2007).

o Freezing days: if either of the following conditions are true:

- 9 hours or more below 34 degrees Fahrenheit $\left({ }^{\circ} \mathrm{F}\right)$.

- Daily mean temperature below $38^{\circ} \mathrm{F}$.

o Nonfreezing days: Days that do not meet the freezing days criterion.

- Heated USGS gages: On freezing days, only USGS rain gages designated as heated were used in this study.

- Definition of missing days:

o Networkwide analyses: For the daily values from the given rain gage network to be included in networkwide analyses in this study, a day had to have at least 10 nonmissing values for that network and the corresponding NEXRAD-MPE values, except during freezing conditions for the USGS gage network, when only the 11 heated gages were considered. In that case, a day had to have at least four nonmissing rain gage and overlying NEXRAD values to be considered.

- Paired rain gage-NEXRAD-MPE cell analyses: Both the given rain gage and its overlying NEXRAD-MPE cell had to be nonmissing for the day to be used.

o Computation of "Cumulative spatial averages": In networkwide analysis, a spatial or network average over nonmissing values on each nonmissing day was computed and added to the network average from the previous day to compute a cumulative spatial average (CSA). 
- Precipitation Adjustment Factors:

o In the DPC-FFSS, a precipitation adjustment factor (PADJ) of 1.14 is applied (Ishii and others, 2003) to the USGS tipping-bucket rain gage data to better match NWS weighing-bucket gage data (Straub and Parmar, 1998; Straub and Bednar, 2002). The same PADJ is applied to the NEXRAD-MPE data, because raw NEXRAD data are corrected to real-time rain gage data (Kitzmiller and others, 2013), which also frequently comes from tipping-bucket gages.

o In this study, the same adjustment factor PADJ $=1.14$ was applied when analyzing the NEXRAD-MPE and USGS gage data.

o No adjustment factor was applied to the CoCoRaHS data in this study.

- An additional snowfall correction factor of 1.40 is also applied in the current DPCFFSS to account for poor gage catch efficiency under snowfall conditions. In this report rain and snow are not explicitly separated; therefore, the snowfall correction factor is not applied. 


\section{Results}

- The main results of the study are presented in figures 4-10.

o Figures 4-7 present cumulative depth plots of two types: (1) double-mass curves showing the relations between cumulative averages at two of the three precipitation data sources and (2) scatterplots showing the relation between pointwise total precipitation at two of the three precipitation data sources. Plots are presented for both freezing or nonfreezing days.

o Table 4 presents tables summarizing the mean percent difference and mean absolute difference statistics from the scatterplots.

o Figure 8 presents plots showing the relation between the pointwise NEXRADMPE percent errors and distance from the KLOT radar.

- Figure 9 compares the probability distributions of the three precipitation data sources through their quantiles.

- Additional results are presented in two appendices.

- Appendix 1 presents daily precipitation quantile comparisons by year.

- Appendix 2 presents the dependence of hourly NEXRAD-MPE precipitation depth, occurrence, and intensity on temperature. 


\section{USGS Rain Gage Data on Nonfreezing Days}
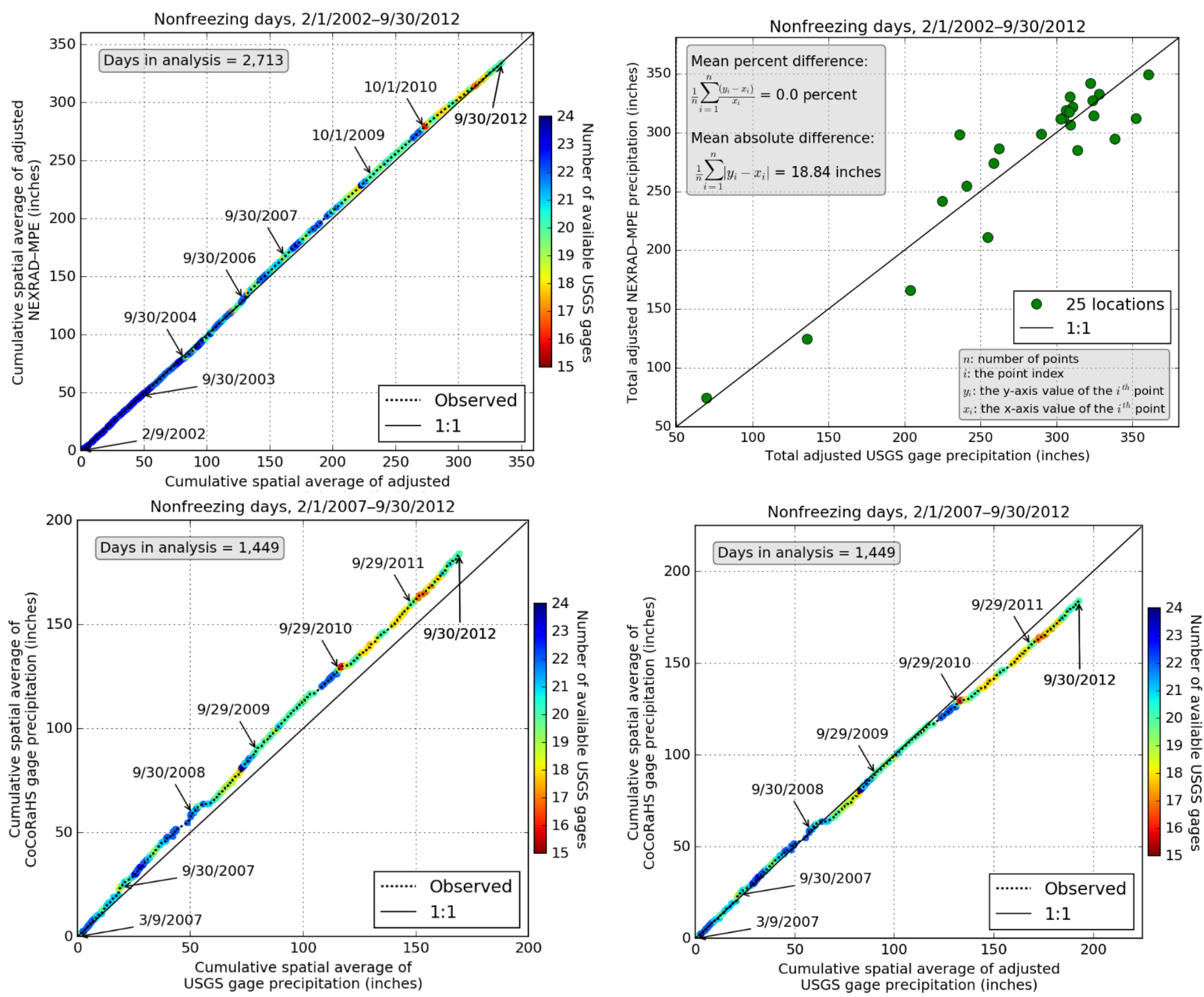

Figure 4. Relation of USGS rain gage precipitation to precipitation from CoCoRaHS network rain gages and NEXRAD-MPE gage-corrected radar on nonfreezing days.

- Description: These plots exhibit the relation of the CSA of adjusted NEXRAD-MPE precipitation to the CSA of adjusted USGS gage precipitation (A); the relation of total adjusted NEXRAD-MPE precipitation to total adjusted USGS precipitation by gage $(B)$; and the relation of the CSA of CoCoRAHS precipitation to the CSAs of unadjusted $(C)$ and adjusted $(D)$ USGS gage precipitation. Periods analyzed were nonfreezing days, Feb. 1, 2002, through Sept. 30, 2012, for top row $(A, B)$, and Feb. 1, 2007, through Sept. 30, 2012 for bottom row $(C, D)$. The color bars indicate the number gages reporting on each day in the analysis period.

- Notes: (1) In these plots, "adjusted" means a PADJ of 1.14 was applied; (2) in the CSA plots $(A, C, D)$, missing days determined according to the networkwide criterion discussed in the "Methods" section were dropped from the analysis; (3) in the plot of total precipitation by gage $(B)$, all available days of data for the given gage-NEXRAD cell pair were used; much of the intergage variation results from different lengths of record.

- Discussion: On nonfreezing days, adjusted USGS rain gage and NEXRAD precipitation depths agree on average in time (A) and space $(B)$, though with scatter. Unadjusted USGS gages underestimate CoCoRaHS precipitation during the early part of the analysis period $(C)$, but when adjusted, overestimate CoCoRaHS precipitation during the latter part of the period $(D)$. 


\section{NEXRAD-MPE Precipitation Data on Nonfreezing Days}
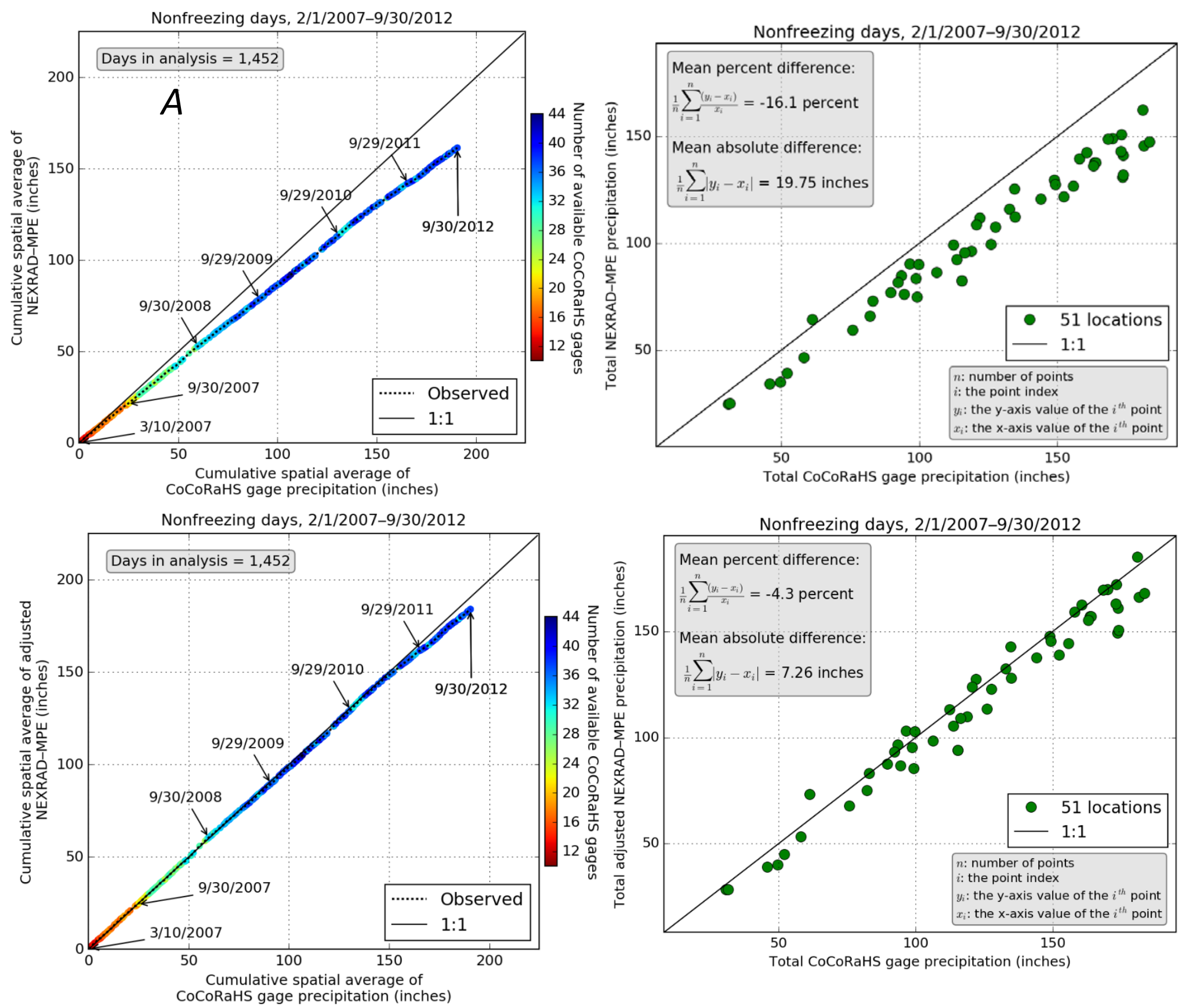

Figure 5. Relation of NEXRAD-MPE gage-corrected radar precipitation to precipitation from CoCoRaHS network rain gages on nonfreezing days.

- Description: These plots exhibit the relation of the CSAs of unadjusted $(A)$ and adjusted $(C)$ NEXRAD-MPE precipitation to the CSA of CoCoRaHS precipitation and the relation of unadjusted $(B)$ and adjusted $(D)$ total NEXRAD-MPE precipitation to total CoCoRaHS precipitation by gage. Periods analyzed were nonfreezing days, Feb. 1, 2007, through Sept. 30, 2012. The color bar indicates the number of gages reporting on each day in the analysis period.

- Notes: (1) In these plots, "adjusted" means a PADJ of 1.14 was applied; (2) in the CSA plots $(A, C)$, missing days determined according to the networkwide criterion given in the "Methods" section were dropped from the analysis; (3) in the plot of total precipitation by gage $(B, D)$, all available days of data for the given gage-NEXRAD cell pair were used; much of the intergage variation results from different lengths of record.

- Discussion: On nonfreezing days, unadjusted NEXRAD-MPE underestimates CoCoRaHS by about 16 percent on average; whereas with adjustment, the underestimate declines to about 4 percent, mostly in the later part of the study period. Scatter in the relation after adjustment is substantially smaller than that between NEXRAD-MPE and USGS gages (compare fig. 4B). 


\section{USGS Rain Gage Data on Freezing Days}
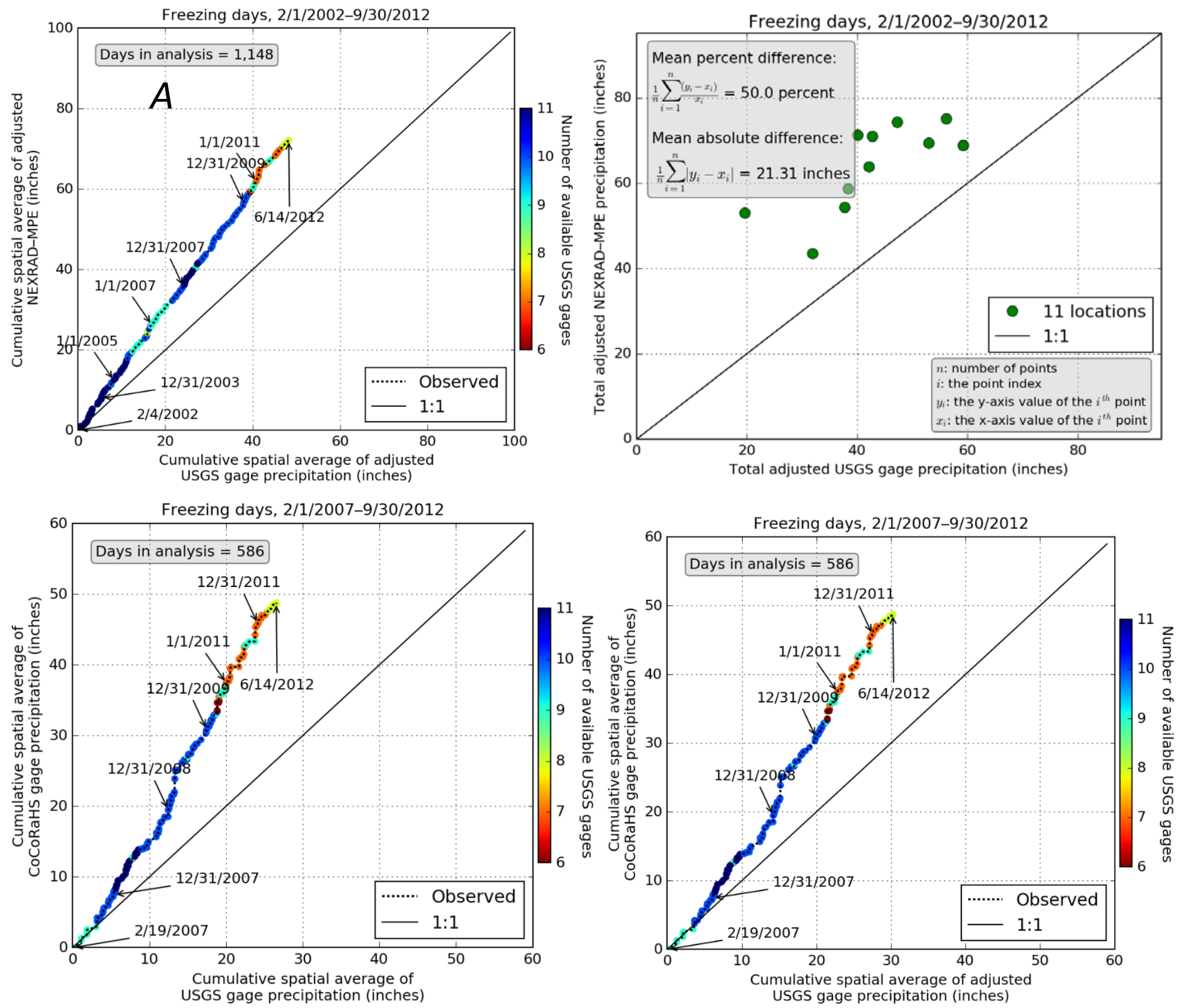

Figure 6. Relation of USGS rain gage precipitation to precipitation from CoCoRaHS network rain gages and NEXRAD-MPE gage-corrected radar on freezing days.

- Description: These plots exhibit the relation of the CSA of adjusted NEXRAD-MPE precipitation to the CSA of adjusted USGS gage precipitation (A); the relation of the CSA of CoCoRaHS precipitation to the CSAs of unadjusted $(C)$ and adjusted (D) USGS gage precipitation; and the relation of total adjusted NEXRAD-MPE precipitation to total USGS precipitation by gage (B). Periods analyzed were freezing days, Feb. 1, 2002, through Sept. 30, 2012 for top row $(A, B)$, and Feb. 1, 2007, through Sept. 30, 2012 for bottom row (C, D). The color bar indicates the number of gages reporting on each day in the analysis period.

- Notes: (1) In these plots, "adjusted" means a PADJ of 1.14 was applied; (2) in the CSA plots $(A, C, D)$, missing days determined according to the networkwide criterion given in the "Methods" section were dropped from the analysis; (3) in the pointwise total precipitation plot $(B)$, all available days of data for the given gage-NEXRAD cell pair were used; much of the intergage variation results from different lengths of record; only the 11 heated USGS rain gages (table 2) were used in the freezing days analysis.

- Discussion: On freezing days, precipitation measured by USGS gages, with or without adjustment, substantially underestimates both NEXRAD-MPE and CoCoRaHS precipitation. 


\section{NEXRAD-MPE Precipitation Data on Freezing Days}
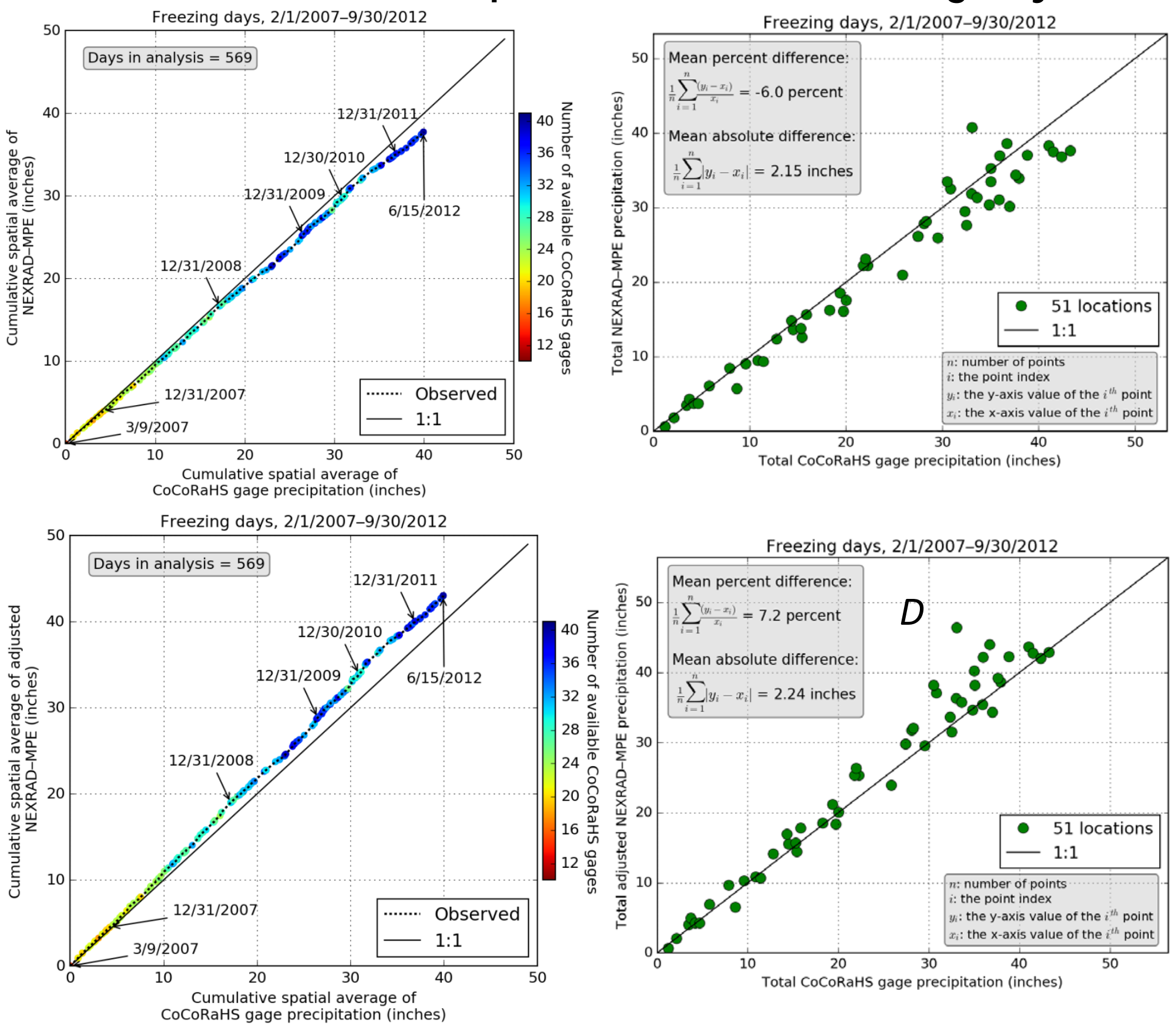

Figure 7. Relation of NEXRAD-MPE gage-corrected radar precipitation to precipitation from CoCoRaHS network rain gages on freezing days.

- Description: These plots exhibit the relations of the CSAs of unadjusted $(A)$ and adjusted (C) NEXRAD-MPE precipitation to the CSA of COCORaHS precipitation and the relation of unadjusted $(B)$ and adjusted $(D)$ total NEXRAD-MPE precipitation to total CoCoRaHS precipitation by gage. Periods analyzed were freezing days, Feb 1, 2007, through Sept. 30, 2012. The color bar indicates the number of gages reporting on each day in the analysis period.

- Notes: (1) In these plots, "adjusted" means a PADJ of 1.14 was applied; (2) in the CSA plots ( $A, C)$, missing days determined according to the networkwide criterion given in the "Methods" section were dropped from the analysis; (3) in the plots of total precipitation by gage $(B, D)$, all available days of data for the given gage-NEXRAD cell pair were used; much of the intergage variation results from different lengths of record.

- Discussion: On freezing days, unadjusted NEXRAD-MPE underestimates CoCoRaHS by about 6 percent on average (panel $B$ ) but overestimates CoCoRaHS by about 7 percent after adjustment (panel $D$ ). The CSA plots (panels $A, C$ ) indicate a reduction in NEXRAD-MPE relative to CoCoRaHS in about the last year of the study period, similar to nonfreezing day results (fig. 5). Scatter in the total precipitation by gage relations is substantially smaller than that between NEXRAD-MPE and USGS gages (fig. 6B). 


\section{Summary of Cumulative Spatial and Total By-Gage Comparisons}

Table 4. Summary of cumulative spatial average and total by-gage comparison results.

[PADJ, precipitation adjustment factor; in., inches; NEXRAD-MPE, Next-Generation Radar-Multisensor Precipitation Estimate; USGS, U.S. Geological Survey; CoCoRaHS, Community Collaborative Rain, Hail, and Snow; dates are expressed as month/day/year]

\begin{tabular}{|c|c|c|c|c|c|c|}
\hline \multicolumn{7}{|c|}{ Nonfreezing days } \\
\hline Dataset A & Dataset B & $\begin{array}{l}\text { Figure } \\
\text { where } \\
\text { plotted }\end{array}$ & PADJ & $\begin{array}{l}\text { Analysis } \\
\text { period }\end{array}$ & $\begin{array}{l}\text { Mean percent } \\
\text { difference }^{1}\end{array}$ & $\begin{array}{c}\text { Mean } \\
\text { absolute } \\
\text { difference } \\
\text { (in.) }\end{array}$ \\
\hline $\begin{array}{l}\text { NEXRAD- } \\
\text { MPE }\end{array}$ & USGS & $4 B$ & 1.14 & $\begin{array}{c}2 / 1 / 2002 \\
-9 / 30 / 2012 \\
\end{array}$ & 0.0 & 18.84 \\
\hline $\begin{array}{l}\text { NEXRAD- } \\
\text { MPE }\end{array}$ & CoCoRaHS & $5 D$ & 1.14 & $\begin{array}{c}2 / 1 / 2007 \\
-9 / 30 / 2012 \\
\end{array}$ & -4.3 & 7.26 \\
\hline USGS & CoCoRaHS & $4 D$ & 1.14 & $\begin{array}{c}2 / 1 / 2007 \\
-9 / 30 / 2012\end{array}$ & 24.6 & 28.93 \\
\hline \multicolumn{7}{|c|}{ Freezing days } \\
\hline Dataset A & Dataset B & $\begin{array}{l}\text { Figure } \\
\text { where } \\
\text { plotted }\end{array}$ & PADJ & $\begin{array}{l}\text { Analysis } \\
\text { period }\end{array}$ & $\begin{array}{l}\text { Mean percent } \\
\text { difference }^{1}\end{array}$ & $\begin{array}{c}\text { Mean } \\
\text { absolute } \\
\text { difference } \\
\text { (in.) }\end{array}$ \\
\hline $\begin{array}{l}\text { NEXRAD- } \\
\text { MPE }\end{array}$ & USGS & $6 B$ & 1.14 & $\begin{array}{c}2 / 1 / 2002 \\
-9 / 30 / 2012 \\
\end{array}$ & 50.0 & 21.31 \\
\hline $\begin{array}{l}\text { NEXRAD- } \\
\text { MPE }\end{array}$ & CoCoRaHS & $7 D$ & 1.14 & $\begin{array}{c}2 / 1 / 2007 \\
-9 / 30 / 2012 \\
\end{array}$ & 7.2 & 2.24 \\
\hline $\begin{array}{l}\text { NEXRAD- } \\
\text { MPE }\end{array}$ & CoCoRaHS & Not plotted & 31.08 & $\begin{array}{c}2 / 1 / 2007 \\
-9 / 30 / 2012 \\
\end{array}$ & 1.6 & 1.84 \\
\hline USGS & CoCoRaHS & $6 D$ & 1.14 & $\begin{array}{c}2 / 1 / 2007 \\
-9 / 30 / 2012 \\
\end{array}$ & $2-61.2$ & 218.52 \\
\hline
\end{tabular}

${ }_{1}^{1}[$ (Dataset A - Dataset B) / Dataset A] $\times 100$

IIn comparisons of the CoCoRaHS and USGS rain gage networks, mean percent difference and mean absolute difference values were computed from the maximum cumulative average values.

${ }^{3}$ On freezing days during the Feb. 1, 2007, to Sept. 30, 2012, CoCoRaHS study period, using PADJ=1.14 overadjusted the NEXRAD-MPE data relative to the CoCoRaHS data. A revised PADJ value of 1.08 minimizes the combined mean percent difference and mean absolute difference.

Discussion: NEXRAD-MPE and USGS precipitation data agree to a similar extent with CoCoRaHS data on nonfreezing days. The fact that the cumulative mean USGS precipitation exceeds that of CoCoRaHS while agreeing with NEXRAD, while at the same time NEXRAD is less in cumulative mean than CoCoRaHS, appears contradictory. This fact, however, evidently arises from differences in time periods being considered, in the method used to compute the mean percent difference (pointwise or cumulative average), in the locations of the gages used, and in days considered missing, and indicates that these differences in cumulative mean are likely not statistically significant. On freezing days, however, the USGS gages substantially underreport CoCoRaHS, whereas NEXRAD-MPE values are in approximate agreement with CoCoRaHS, with a modest overestimation by adjusted NEXRAD-MPE. The adjusted NEXRAD-MPE's overestimation during freezing conditions would be minimized by using an adjustment factor of PADJ=1.08 instead of the standard PADJ=1.14, but the amount of data may not be sufficient to indicate such a revision would be reliable. 


\section{NEXRAD-MPE-Gage Differences and Gage-to-Radar Distance}

\section{Nonfreezing Days}
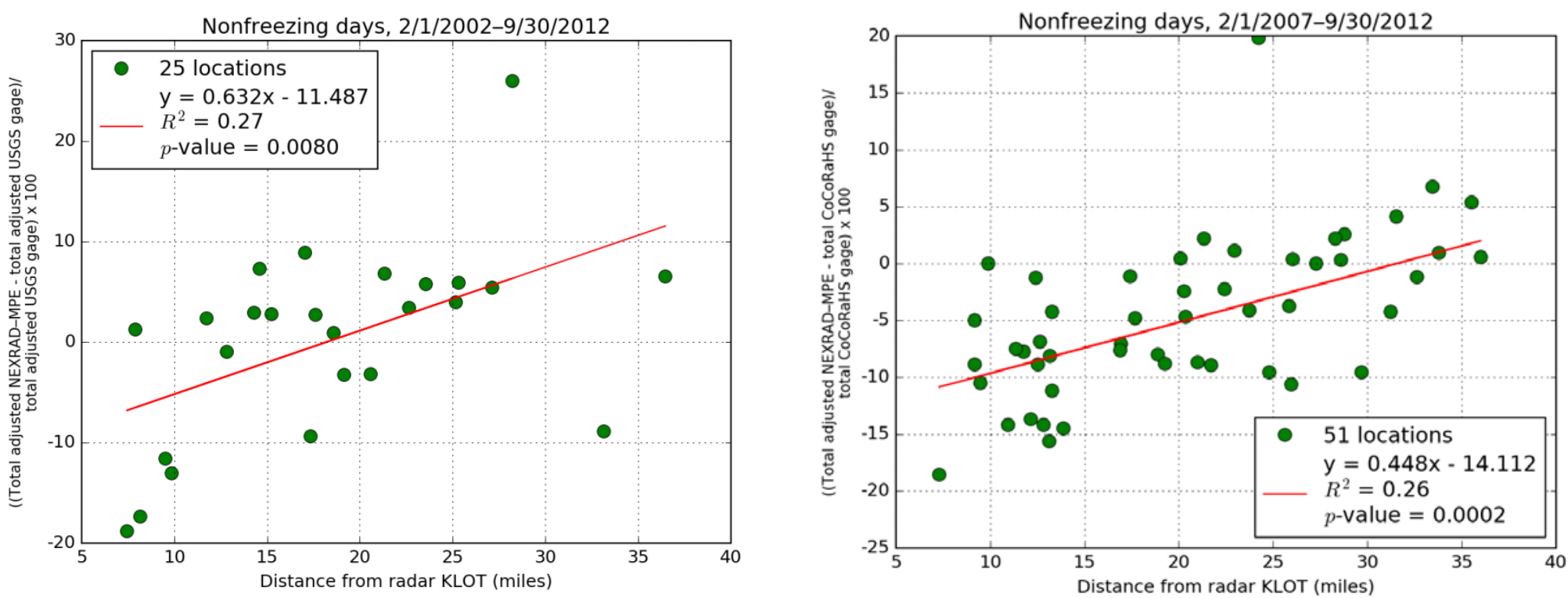

\section{Freezing Days}
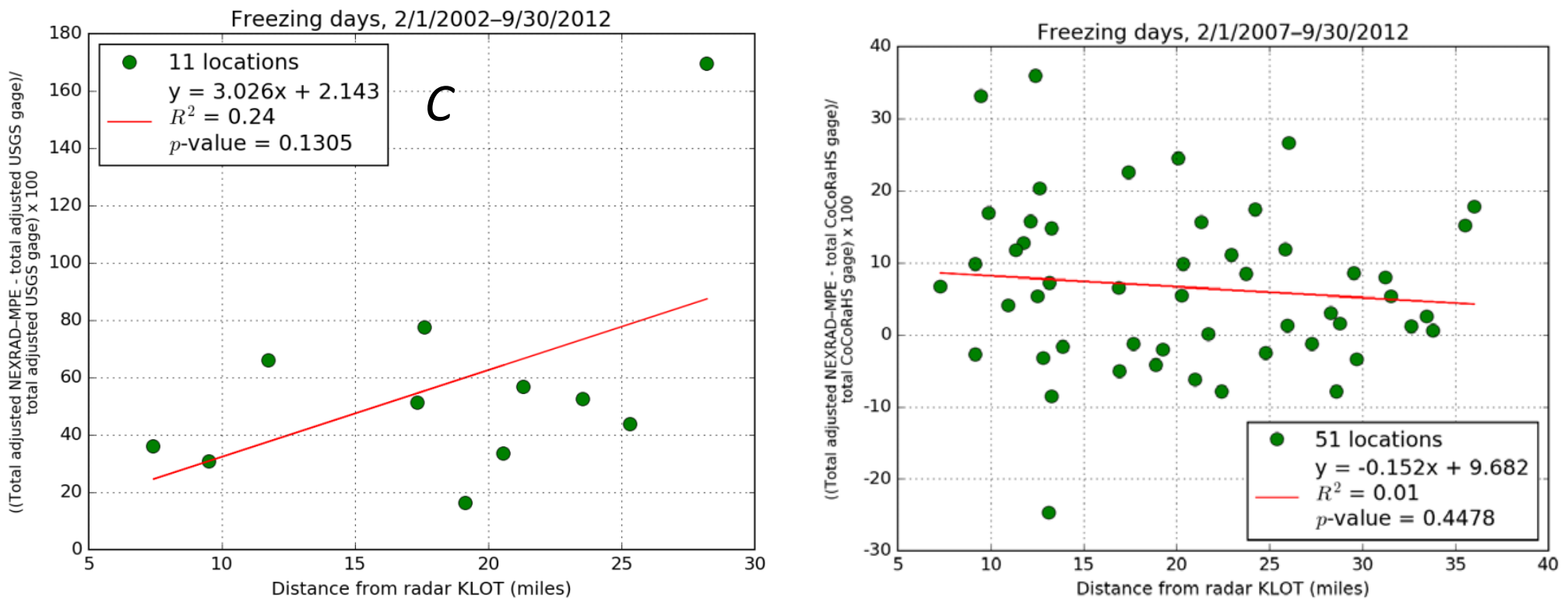

Figure 8. Relations between NEXRAD-MPE-gage differences and gage-to-radar distance.

- Description: These plots exhibit the relation between percent difference between total adjusted NEXRAD-MPE precipitation and that at corresponding USGS $(A, C)$ and CoCoRaHS $(B, D)$ gages on nonfreezing $(A, B)$ and freezing $(C, D)$ days, as a function of the distance from the KLOT radar location (figs. 2, 3). Periods of analysis were nonfreezing $(A)$ and freezing $(B)$ days, Feb. 1, 2002, through Sept. 30, 2012, and nonfreezing $(B)$ and freezing $(D)$ days, Feb. 1 , 2007, through Sept. 30, 2012.

- Notes: The NEXRAD-MPE and USGS gage precipitation data in these plots were adjusted with a PADJ of 1.14; $R^{2}$ indicates the coefficient of determination; and the $p$-value is the probability that the null hypothesis of zero slope is true given the observations (so small $p$-values indicate that it is unlikely that the true slope is zero). In the equation, ' $y$ ' is the value on the vertical axis and ' $x$ ' is the value on the horizontal axis.

- Discussion: On nonfreezing days, there are significantly increasing trends in the percent differences in total precipitation between NEXRAD-MPE and both sets of gage data of about 0.5 percent per mile as a function of distance from the KLOT radar. On freezing days, the trends are not significant. 


\section{Daily Precipitation Quantile Comparisons}
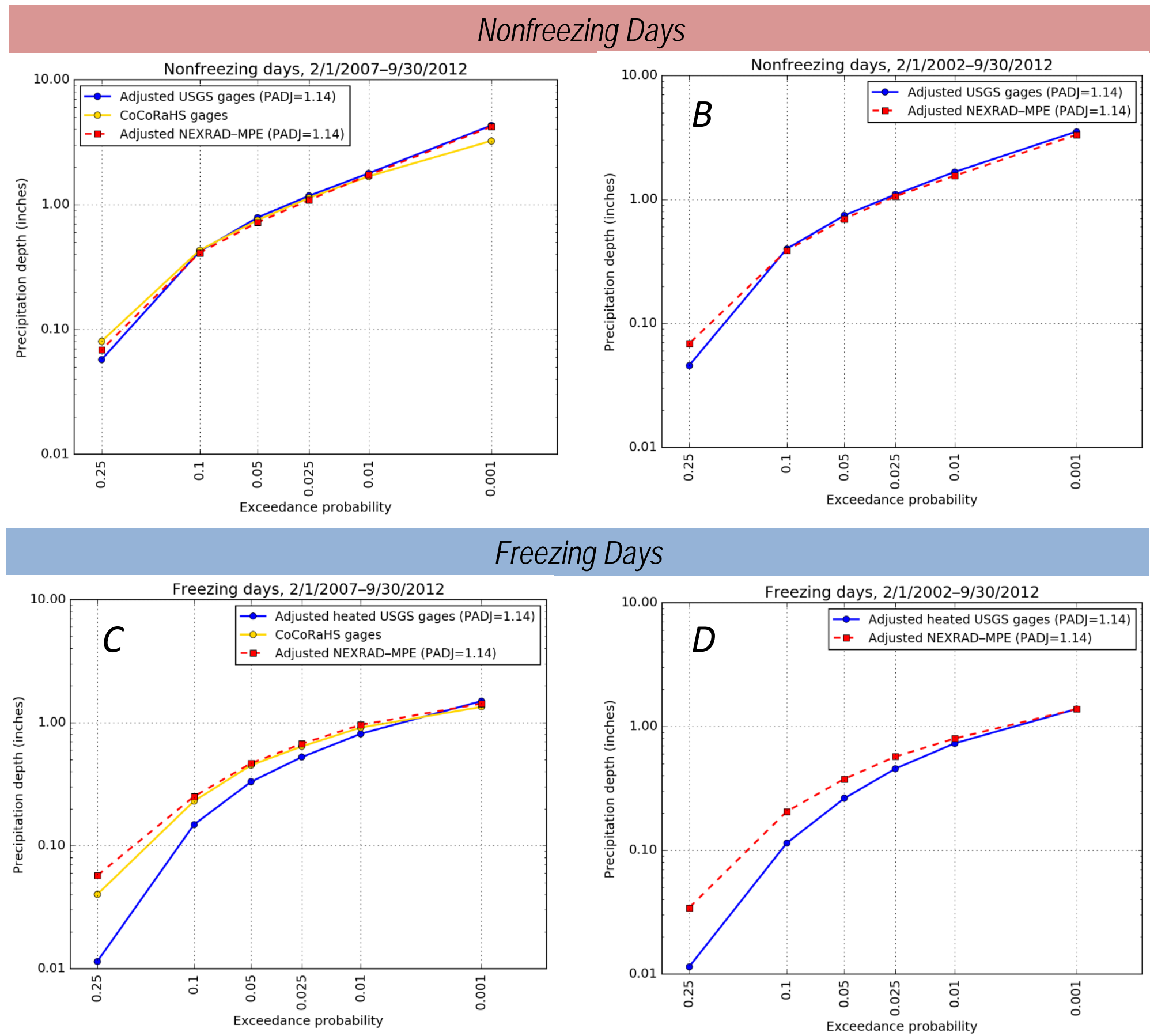

Freezing Days

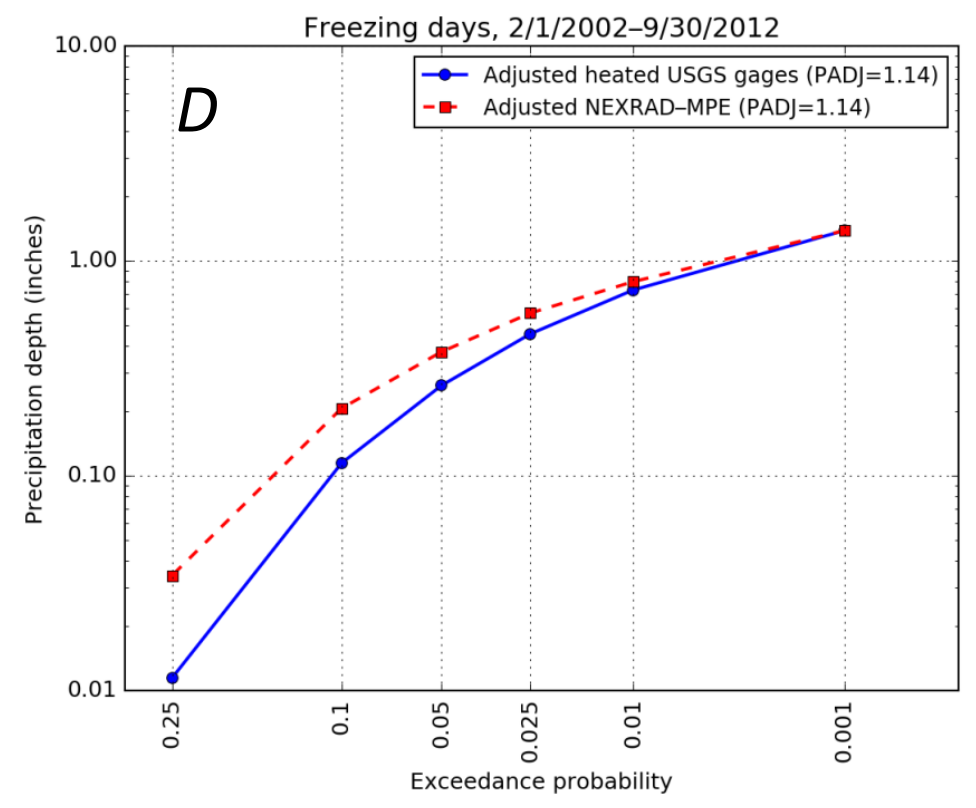

Figure 9. Relations between daily precipitation quantiles and exceedance probability.

- Description: These plots exhibit daily precipitation quantiles at exceedance probabilities of $0.25,0.10,0.5,0.25,0.01$, and 0.001 for all NEXRAD-MPE cells, USGS gages, and CoCoRaHS gages for the full record of available data during Feb. 1, 2007, through Sept. 30, $2012(A, C)$ and Feb. 1, 2002, through Sept. 30, $2012(B, D)$ on nonfreezing $(A, B)$ and freezing $(C, D)$ days.

- Example: The quantile with exceedance probability of 0.05 (5 percent) gives the daily precipitation depth that is exceeded on 5 percent of days.

- Notes: NEXRAD-MPE and USGS gage values were adjusted by the PADJ=1.14. Only heated USGS gages were used for freezing days analyses. Data analyzed includes all precipitation values, including zeroes. Appendix 1 includes daily precipitation quantiles by year.

- Discussion: Results indicate that all three data sources have similar precipitation distributions during nonfreezing days. On freezing days, the NEXRAD-MPE data show a good comparison to the CoCoRaHS data, whereas the USGS values are progressively smaller than the others as exceedance probability increases, a result that seems consistent with the effects of heating the USGS gages. 


\section{Summary and Conclusions}

- Methods Summary: Precipitation data in and near DuPage County, Illinois, from three sources were compared: (1) Next-Generation Radar (NEXRAD)-Multisensor Precipitation Estimate (MPE) gage-corrected radar, (2) an automated tipping-bucket rain gage network operated by the U.S. Geological Survey (USGS), and (3) the Community Cooperative Rain, Hail, and Snow (CoCoRaHS) rain gage network. Daily precipitation values from gages were paired with the overlapping NEXRAD-MPE cell values, and the accumulated data for all cells/gages were analyzed for long-term differences. Data from Feb. 1, 2002 to Sept. 30, 2012, were used for NEXRAD-MPE and USGS gages, and data from Feb. 1, 2007, to Sept. 30, 2012, were used for CoCoRaHS gages. Based on previous comparisons of tippingbucket and weighing-bucket rain gages in the region, NEXRAD-MPE and USGS gage values were adjusted by applying a factor of 1.14 .

- Results Highlights:

o All stated results include precipitation adjustment of 1.14 to NEXRAD-MPE and USGS rain gage precipitation.

o Nonfreezing day results:

- NEXRAD-MPE and USGS gage-based accumulated precipitation depths were both similar on average to $\mathrm{CoCoRaHs}$ accumulated precipitation depths on non--freezing days during the Feb. 1, 2007, to Sept. 30, 2012, study period.

- NEXRAD-MPE percent differences in total precipitation from both CoCoRaHS and USGS rain gages increased significantly with distance from the KLOT radar.

- Precipitation quantiles indicate very similar results among the three precipitation products during nonfreezing conditions.

o Freezing day results:

- Heated USGS gages exhibit a substantial low bias during the freezing days (CoCoRaHS and NEXRAD-MPE data were higher, on average, by 61 and 50 percent, respectively).

- NEXRAD-MPE provides on average a relatively accurate precipitation product (7.2 percent average difference from CoCoRaHS) compared to the USGS tipping-bucket gage network on freezing days.

- NEXRAD-MPE quantiles are in good agreement with CoCoRaHS gages during freezing conditions, but USGS gages substantially underestimate CoCoRaHS quantiles for all but the lowest exceedance probabilities. 
o Results on the temperature distribution of precipitation:

- Most precipitation in the study area occurred at moderate temperatures of 30 to 74 degrees Fahrenheit $\left({ }^{\circ} \mathrm{F}\right)$.

- When precipitation was occurring, its average intensity increased with temperatures to about $86^{\circ} \mathrm{F}$.

- Discussion and Prospects:

o Freezing precipitation is known to be challenging to measure, especially in tipping-bucket rain gages (Rasmussen and others, 2012). The convenience, short response, reporting times, and relative accuracy of such gages during nonfreezing conditions may, however, offset that weakness for this application.

o NEXRAD hardware and NEXRAD-based precipitation products continue to evolve, suggesting that ongoing evaluations of their accuracy would be valuable:

- Higher ("super") resolution data in the original polar coordinates began to be produced in 2008 (Torres and Curtis, 2007; Seo and Krajewski, 2010).

- The NEXRAD radars were recently $(2011-13)$ upgraded nationwide to feature dual-polarization; in particular, the KLOT radar was upgraded as of Oct. 31, 2011 (National Oceanic and Atmospheric Administration, 2017).

This upgrade, combined with associated data processing algorithms, should aid in discrimination of hydometeor types and improve the estimation of frozen precipitation, and may reduce range-dependent errors (Cunha and others, 2013; Zrnic and others, 2014).

0 The higher mean precipitation intensity seen at higher temperatures suggests that additional analyses of these precipitation data, as a function of intensity and temperature, might yield additional insights regarding precipitation data accuracy under different conditions; for example, stratiform and convective precipitation events. 


\section{References Cited}

Bera, M., 2014, Watershed Data Management (WDM) database for Salt Creek streamflow simulation, DuPage County, Illinois, water years 2005-11: U.S. Geological Survey Data Series 870, 18 p., accessed October 25, 2016, at https://dx.doi.org/10.3133/ds870.

Bera, M., 2017, Watershed Data Management (WDM) database for West Branch DuPage River streamflow simulation, DuPage County, Illinois, January 1, 2007, through September 30, 2013: U.S. Geological Survey Open-File Report 2017-1099, 39 p., accessed November 7, 2017, at https://doi.org/10.3133/ofr20171099.

Bera, M., and Over, T. M., 2016, Meteorological database, Argonne National Laboratory, Illinois, January 1, 1948-September 30, 2014: U.S. Geological Survey data release, accessed December 4, 2017, at https://dx.doi.org/10.5066/F7Q52MQG.

Cunha, L.K., Smith, J.A., Baeck, M.L., and Krajewski, W.F., 2013, An early performance evaluation of the NEXRAD dualpolarization radar rainfall estimates for urban flood applications: Weather and Forecasting, v. 28, p. 1478-1497.

Eldardiry, H., Habib, E., Zhang, Y., and Graschel, J., 2017, Artifacts in stage IV NWS real-time multisensor precipitation estimates and impacts on identification of maximum series: Journal of Hydrologic Engineering, v. 22, no. 5, accessed September 22, 2017, at https://doi.org/10.1061/(ASCE)HE.1943-5584.0001291.

Fulton, R.A., 1998, WSR-88D polar-to-HRAP mapping: Silver Spring, Md., National Weather Service, Office of Hydrology, Hydrologic Research Laboratory Technical Memorandum, $34 \mathrm{p}$.

Ishii, A.L., Charlton, T.J., Ortel, T.W., and Vonnahme, C.C., 1998, Modeling system for near real-time flood simulation for Salt Creek in Du Page County, Illinois, in Proceedings of the First Federal Interagency Hydrologic Modeling Conference, April 19-28, 1998: Las Vegas, Nev., Tropicana Hotel, p. 8.51-8.58.

Ishii, A.L., Ortel, T.W., Over, T.M., Murphy, E.A., 2003, Nexrad and rainfall-gage precipitation inputs for near real-time flood simulation of Salt Creek in Du Page County, Illinois (abstract), in National Hydrologic Warning Council/Southwestern Association of ALERT Systems Abstracts: Dallas, Tex., p. 43.

Jayakrishnan, R., Srinivasan, R., and Arnold, J.G., 2004, Comparison of rain gage and WSR-88D stage III precipitation data over the Texas-Gulf basin: Journal of Hydrology, v. 292, no. 1, p. 135-152.

Kim, S., and Brubaker, K.L., 2014, Comparison of gauge and MPE precipitation data for the Chesapeake Bay Watershed Model: Journal of Hydrologic Engineering, v. 19, no. 5, p. 1042-1047.

Kitzmiller, D., Miller, D., Fulton, R., Ding, F., 2013, Radar and multisensor precipitation estimation techniques in National Weather Service hydrologic operations: Journal of Hydrologic Engineering, v. 18, no. 2, p. 133-142.

Murphy, E.A., and Ishii, A.L., 2006, Watershed Data Management (WDM) database for Salt Creek streamflow simulation, DuPage County, Illinois: U.S. Geological Survey Open-File Report 2006-1248, 34 p.

National Oceanic and Atmospheric Administration, 2014, Global historical climatology network: National Centers for Environmental Information web page, accessed March 15, 2014, at https://www.ncdc.noaa.gov/data-access/land-basedstation-data/land-based-datasets/global-historical-climatology-network-ghcn.

National Oceanic and Atmospheric Administration, 2017, WSR-88D dual polarization deployment progress: Radar Operations Center, National Weather Service web page, accessed September 20, 2017, at https://www.roc.noaa.gov/WSR88D/PublicDocs/DualPol/DPstatus.pdf.

Ortel, T.W., and Spies, R.R., 2015, NEXRAD quantitative precipitation estimates, data acquisition, and processing for the DuPage County, Illinois, streamflow-simulation modeling system: U.S. Geological Survey Fact Sheet 2015-3076, 2 p., accessed December 4, 2017, at https://dx.doi.org/10.3133/fs20153076. 
Over, T.M., Murphy, E.A., Ortel, T.W., and Ishii, A.L., 2007, Comparisons between NEXRAD radar and tipping-bucket gage rainfall data-A case study for DuPage County, Illinois, in Proceedings, World Environmental and Water Resources Congress 2007: American Society of Civil Engineers, 14 p.

Over, T.M., Price, T.H., and Ishii, A.L., 2010, Development and analysis of a meteorological database, Argonne National Laboratory, Illinois: U.S. Geological Survey Open-File Report 2010-1220, 67 p.

Price, K., Purucker, S.T., Kraemer, S.R., Babendreier, J.E., and Knightes, C.D., 2014, Comparison of radar and gauge precipitation data in watershed models across varying spatial and temporal scales: Hydrological Processes, v. 28, no. 9, p. 3505-3520.

Rasmussen, R., Baker, B., Kochendorfer, J., Meyers, T., Landolt, S., Fischer, A.P., Black, J., Thériault, J.M., Kucera, P., Gochis, D., Smith, C., Nitu, R., Hall, M., Ikeda, K., and Gutmann, E., 2012, How well are we measuring snow?-The NOAA/FAA/NCAR winter precipitation test bed: Bulletin of the American Meteorological Society, v. 93, no. 6, p. 811-829.

Reges, H.W., Doesken, N., Turner, J., Newman, N., Bergantino, A., and Schwalbe, Z., 2016, CoCoRaHS-The evolution and accomplishments of a volunteer rain gauge network: Bulletin of the American Meteorological Society, v. 98, no. 10, p. 1831-1846.

Seo, B.C., and Krajewski, W.F., 2010, Scale dependence of radar rainfall uncertainty-Initial evaluation of NEXRAD's new super-resolution data for hydrologic applications: Journal of Hydrometeorology, v. 11, no. 5, p. 1191-1198.

Simpson, M.J., Hirsch, A., Grempler, K., and Lupo, A., 2017, The importance of choosing precipitation datasets: Hydrological Processes, v. 31, p. 4600-4612, accessed November 1, 2017, at https://doi.org/10.1002/hyp.11381.

Straub, T.D., and Parmar, P.S., 1998, Comparison of rainfall records collected by different rain-gage networks, in Proceedings of the First Federal Interagency Hydrologic Modeling Conference, April 19-28, 1998: Las Vegas, Nev., Tropicana Hotel, p. 7.25-7.32.

Straub, T.D., and Bednar, R.J., 2002, Bias in runoff parameter estimation induced by rainfall data, in Proceedings of the Second Federal Interagency Hydrologic Modeling Conference, July 28-August 1, 2002: Las Vegas, Nev., Riviera Hotel, $6 \mathrm{p}$.

Torres, S.M., and Curtis, C.D., 2007, Initial implementation of super-resolution data on the NEXRAD network-Extended abstract, in Proceedings, 23rd Conference on Interactive Information Processing Systems, 87th American Meteorological Society Annual Meeting, January 13-18, 2007: San Antonio, Tex., 6 p., accessed April 25, 2008, at https://ams.confex.com/ams/87ANNUAL/webprogram/Paper116240.html.

U.S. Geological Survey, 2014, USGS Surface-Water Data for the Nation-National Water Information System web page, accessed April 2, 2014, at https://waterdata.usgs.gov/nwis/sw.

Westcott, N.E., and Knapp, H.V., 2006, Evaluation of the accuracy of radar-based precipitation for use in flow forecasting for the Fox Chain of lakes: Illinois State Water Survey Contract Report 2006-05, 22 p.

Westcott, N.E., Knapp, H.V., and Hilberg, S.D., 2008, Comparison of gage and multi-sensor precipitation estimates over a range of spatial and temporal scales in the Midwestern United States: Journal of Hydrology, v. 351, no. 1, p. 1-12.

Young, C.B., Bradley, A.A., Krajewski, W.F., Kruger, A., and Morrissey, M.L., 2000, Evaluating NEXRAD multisensor precipitation estimates for operational hydrologic forecasting: Journal of Hydrometeorology, v. 1, p. 241-254.

Zrnic, D., Lee, R., and Boettcher, J.B., 2014, Polarimetric WSR-88D network, observation highlights, in Proceedings, European Conference on Radar in Meteorology and Hydrology (ERAD), September 1-5, 2014: Garmisch-Partenkirchen, Germany, 9 p., accessed July 21, 2017, at http://www.pa.op.dlr.de/erad2014/programme/ExtendedAbstracts/144 Zrnic.pdf. 


\section{Appendix 1. Daily Precipitation Quantile Comparisons by Year}



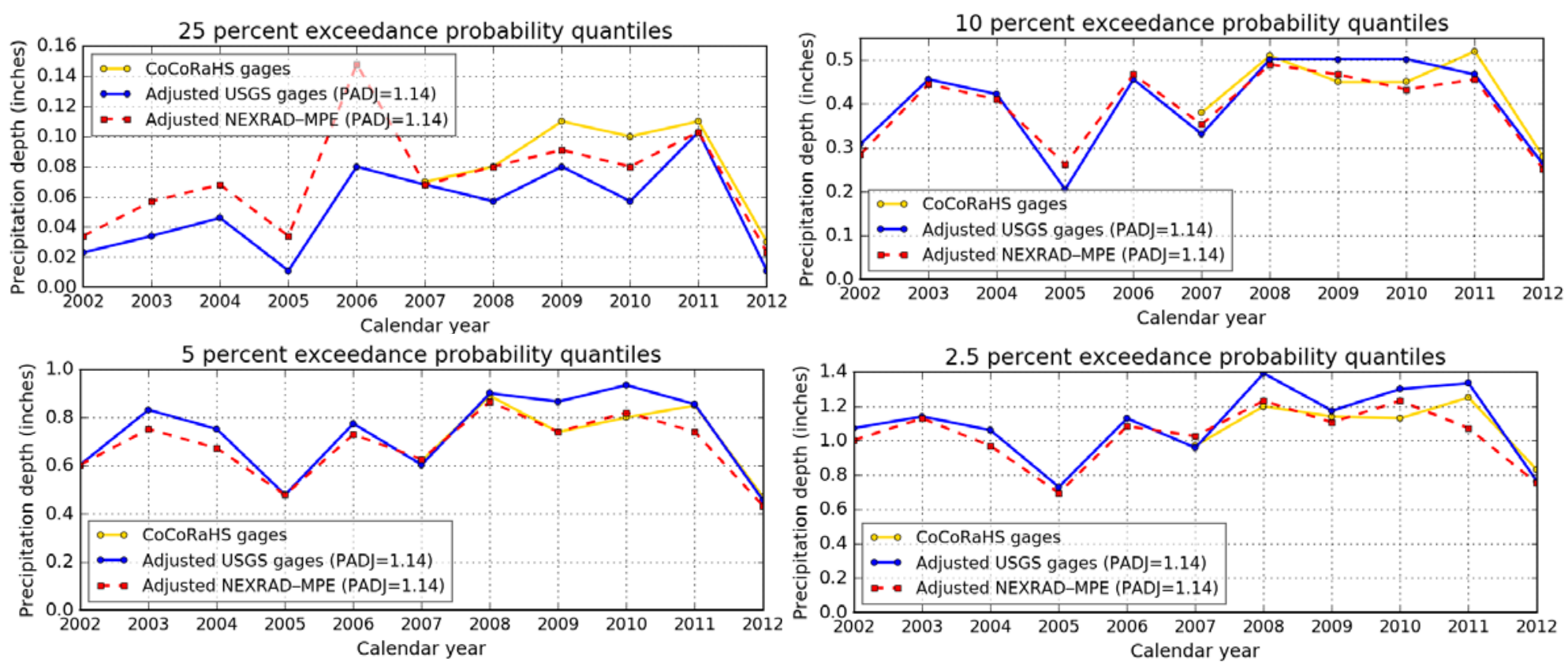

Figure 1-1. Comparison of daily precipitation quantiles by year during nonfreezing days.
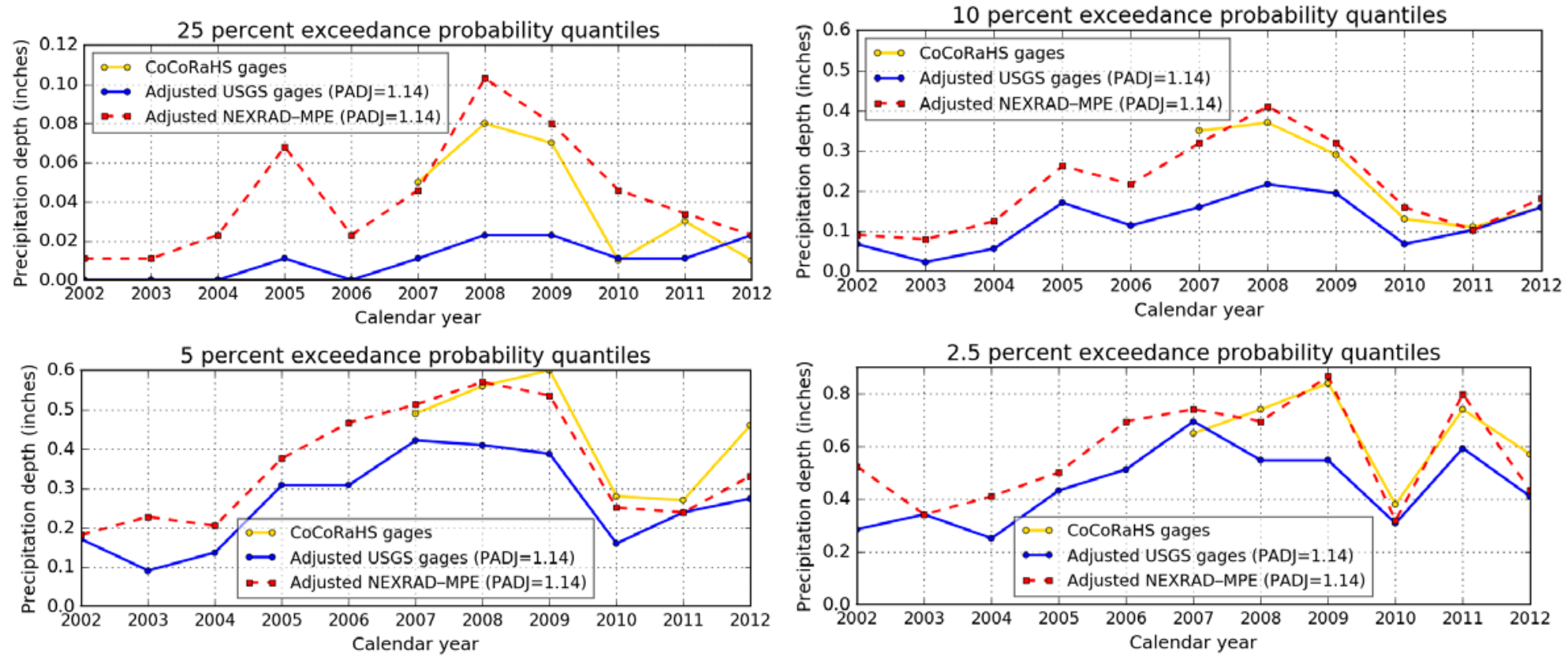

Figure 1-2. Comparison of daily precipitation quantiles by year during freezing days.

- Description: These plots exhibit daily precipitation quantiles at exceedance probabilities of 25, 10, 5, and 2.5 percent for combined values from all available U.S. Geological Survey (USGS) and Community Collaborative Rain, Hail, and Snow (CoCoRaHS) gages and Next-Generation Radar (NEXRAD)-Multisensor Precipitation Estimate (MPE) cells on nonfreezing (fig. 1-1) and freezing (fig. 1-2) days by year from 2002 to 2012 (for USGS gages and NEXRAD-MPE cells) and from 2007 to 2012 (for CoCoRaHS gages).

- Note: All values from USGS gages and NEXRAD-MPE were adjusted with precipitation adjustment factor (PADJ) =1.14.

- Discussion: During nonfreezing days (fig. 1-1), the largest differences among the quantiles occur for the 25 percent quantile when NEXRAD and CoCoRaHS exceed USGS gage quantiles during most years. For the other quantiles, substantial differences only occur during a few years, most consistently for 2009-10 when NEXRAD and CoCoRaHS quantiles mostly agree but are exceeded by the USGS gage quantiles. During freezing days (fig. 1-2), as expected from the multiyear quantile (fig. 9) and cumulative average results (table 4), USGS gage quantiles are generally less than those of NEXRAD and $\mathrm{CoCoRaHS}$, with differences increasing with increasing exceedance probability (lower precipitation intensity). NEXRAD and CoCoRaHS quantiles track together except for 25 percent quantile when NEXRAD-MPE is usually higher. 


\section{Appendix 2. \\ Dependence of NEXRAD-MPE Precipitation on Temperature}




\section{Depth and Occurrence}

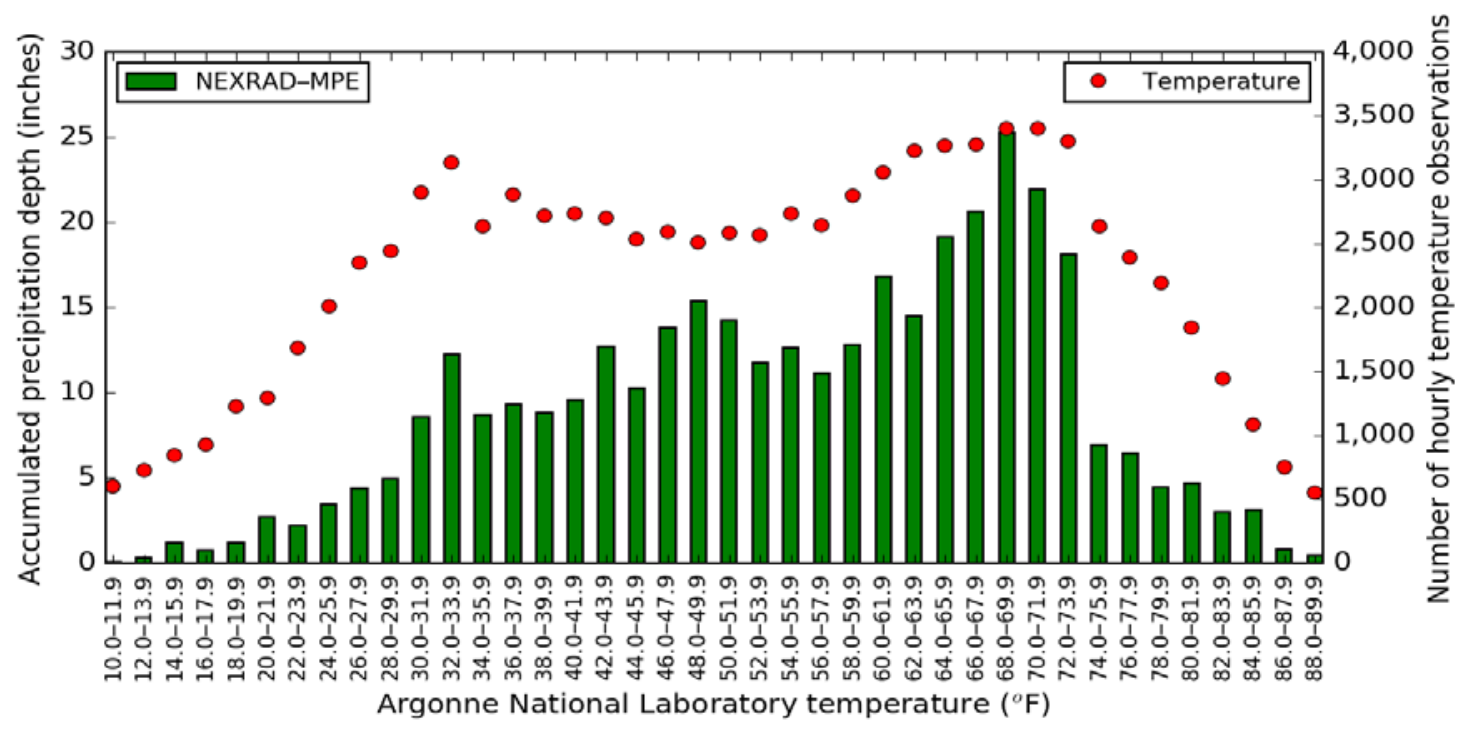

Figure 2-1. Spatial mean total NEXRAD-MPE precipitation depth and temperature frequency by temperature using data from Feb. 1, 2002, through Sept. 30, 2012.

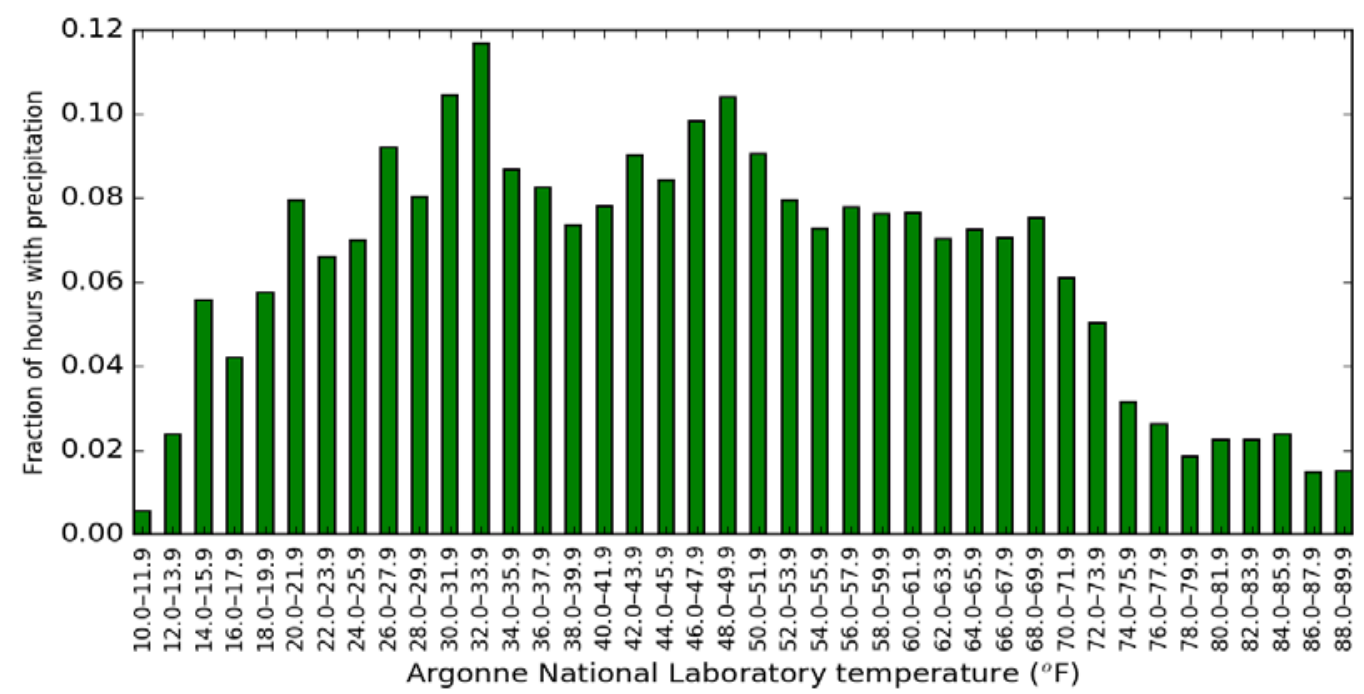

Figure 2-2. Fraction of hours with NEXRAD-MPE precipitation by temperature using data from Feb. 1, 2002, through Sept. 30, 2012.

- Description: Figure 2-1 exhibits the number of hourly Argonne National Laboratory (ANL) air temperature observations (red markers, right axis) and adjusted Next Generation Radar-Multisensor Precipitation Estimate (NEXRAD-MPE) spatial mean total precipitation (green bars, left axis) by 2 degrees Fahrenheit $\left({ }^{\circ} \mathrm{F}\right)$ temperature bin. Figure $2-2$ exhibits the fraction of hours with at least 0.01 inch of NEXRAD-MPE precipitation by $2^{\circ} \mathrm{F}$ temperature bin.

- Notes: Precipitation data used in these plots are the hourly values from the 50 NEXRAD-MPE cells used in this study and are not adjusted. Data are sorted into $2^{\circ} \mathrm{F}$ bins for the period Feb. 1, 2002, through Sept. 30, 2012. Data for temperatures $>89.9^{\circ} \mathrm{F}$ and $<10^{\circ} \mathrm{F}$ are not plotted; these make up 0.6 and 2.3 percent, respectively, of the hours, and 0.09 and 0.13 percent, respectively, of the precipitation depth.

- Discussion: Figure 2-1: The most common air temperatures are those between 30.0 and $73.9{ }^{\circ} \mathrm{F}$, constituting 68.2 percent of the hours, and accounting for 85.6 percent of the precipitation depth. Nonfreezing temperatures $32{ }^{\circ} \mathrm{F}$ and higher account for 79.5 percent of the hours and 91.6 percent of the precipitation. Figure 2-2: Precipitation occurs for a fraction of at least 0.06 of the hours for temperatures from 20 to $71.9^{\circ} \mathrm{F}$, and is less likely for higher and lower temperatures. Precipitation is most likely to occur around freezing (from 30 to $33.9^{\circ} \mathrm{F}$ ), when it occurs with a fraction of more than 0.10 of the hours, and has another maximum fraction exceeding 0.10 for the $48-49.9^{\circ} \mathrm{F}$ bin. The relatively high accumulated depth of precipitation for higher temperatures combined with lower likelihood of precipitation implies that mean precipitation rates, when precipitation is occurring, are higher for higher temperatures (fig. 2-4). 


\section{Intensity}

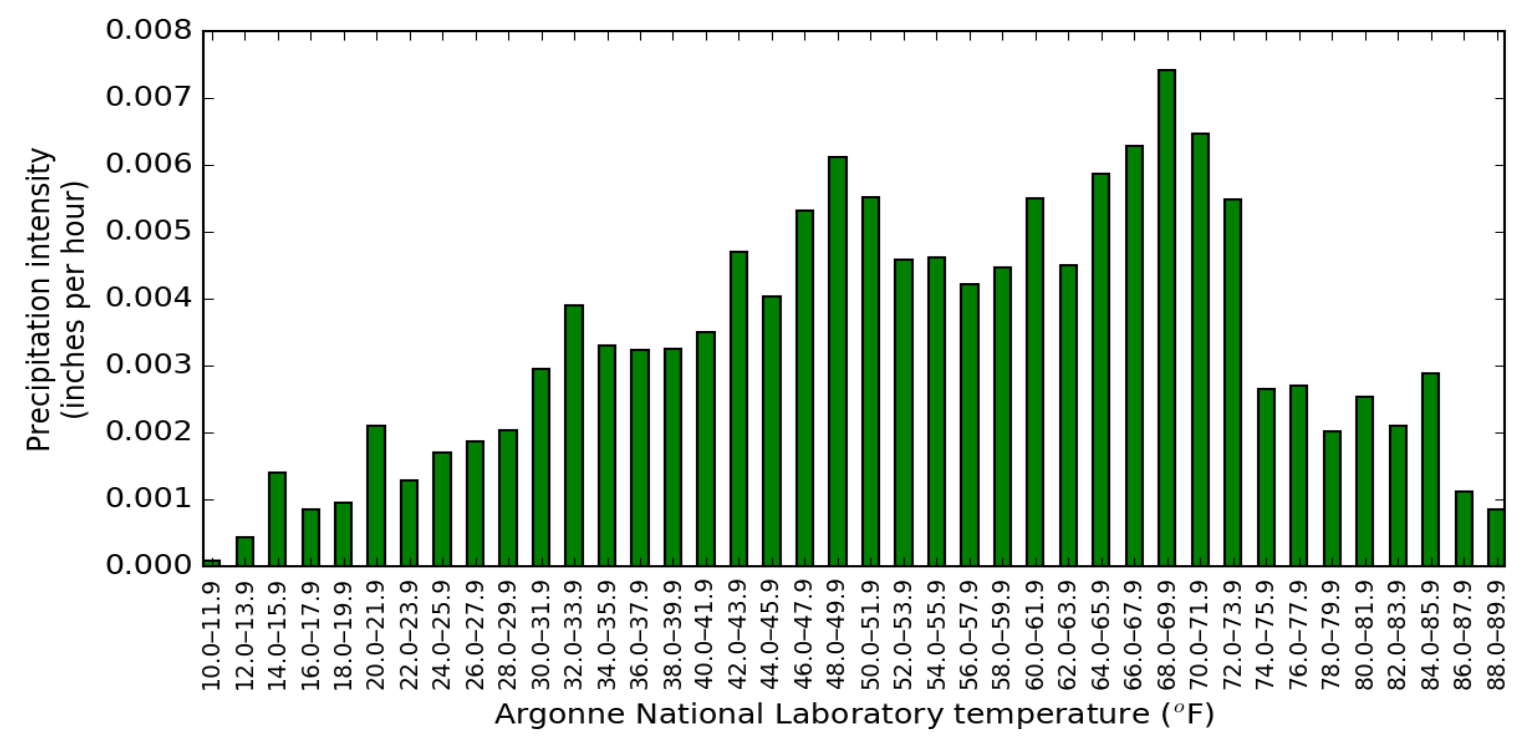

Figure 2-3. Spatial mean NEXRAD-MPE hourly average precipitation intensity by temperature during all hours from Feb. 1, 2002, through Sept. 30, 2012.

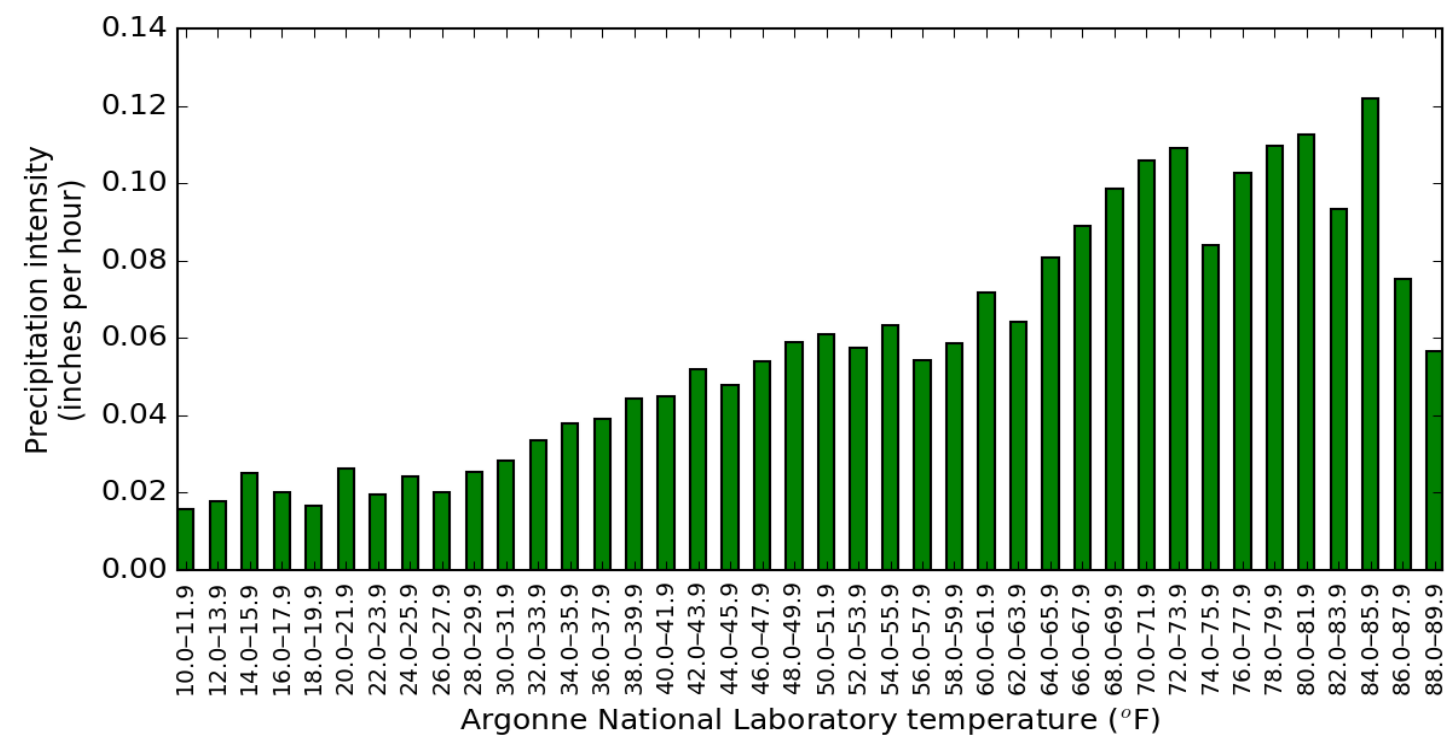

Figure 2-4. Spatial mean NEXRAD-MPE hourly average precipitation intensity by temperature during hours with reported precipitation from Feb. 1, 2002, through Sept. 30, 2012.

- Description: These figures exhibit mean hourly NEXRAD-MPE precipitation, including zero precipitation (fig. 2-3) and all hours with reported precipitation (precipitation intensity) greater than or equal to 0.01 (fig. 2-4) with air temperature in degrees Fahrenheit $\left({ }^{\circ} \mathrm{F}\right)$.

- Note: Precipitation data used in these plots are the hourly values from the 50 NEXRAD-MPE cells used in this study and are not adjusted. Data are sorted into $2^{\circ} \mathrm{F}$ bins for the period Feb. 1, 2002, through Sept. 30, 2012. Data for temperatures $>89.9^{\circ} \mathrm{F}$ and $<10^{\circ} \mathrm{F}$ are not plotted; these make up 0.6 and 2.3 percent, respectively, of the hours, and 0.09 and 0.13 percent, respectively, of the precipitation depth.

- Discussion: Mean hourly precipitation (including hours with no precipitation) was lower during the coldest ( $\left.\angle 30^{\circ} \mathrm{F}\right)$ and warmest $\left(>74{ }^{\circ} \mathrm{F}\right.$ ) temperatures (fig. $2-3$ ), but given there was precipitation, the average intensity generally increased with temperature until about $86^{\circ} \mathrm{F}$, with values around $\sim 0.10$ inches/hour during temperatures of $68-86^{\circ} \mathrm{F}$ (fig. 2-4). The increase of mean intensity during precipitation with temperature indicates the effects of more convective as compared to stratiform (frontal) precipitation with increasing temperature, as convective precipitation is associated with the summer season in the midlatitudes and generally has higher intensities than frontal precipitation (Henderson-Sellers and Robinson, 1986, p. 132-135, 140-141). 


\section{Reference Cited}

Henderson-Sellers, A., and Robinson, P.J., 1986, Contemporary climatology: Harlow, England, Longman Scientific \& Technical, 439 p. 